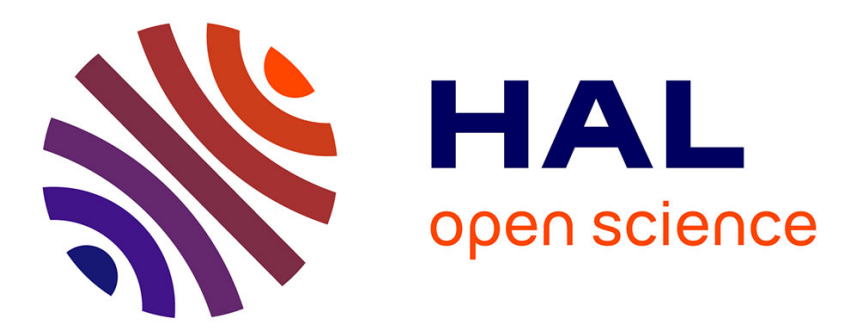

\title{
Determination of uptake kinetics and sampling rates for 56 organic micropollutants with "pharmaceutical" POCIS
}

N. Morin, Julien Camilleri, Cécile Cren-Olivé, Marina Coquery, Cecile Miege

\section{- To cite this version:}

N. Morin, Julien Camilleri, Cécile Cren-Olivé, Marina Coquery, Cecile Miege. Determination of uptake kinetics and sampling rates for 56 organic micropollutants with "pharmaceutical" POCIS. Talanta, 2013, 109, p. 61 - p. 73 . 10.1016/j.talanta.2013.01.058 . hal-00937619

\section{HAL Id: hal-00937619 https://hal.science/hal-00937619}

Submitted on 28 Jan 2014

HAL is a multi-disciplinary open access archive for the deposit and dissemination of scientific research documents, whether they are published or not. The documents may come from teaching and research institutions in France or abroad, or from public or private research centers.
L'archive ouverte pluridisciplinaire HAL, est destinée au dépôt et à la diffusion de documents scientifiques de niveau recherche, publiés ou non, émanant des établissements d'enseignement et de recherche français ou étrangers, des laboratoires publics ou privés. 


\section{Determination of uptake kinetics and sampling rates for $\mathbf{5 6}$ 2 organic micropollutants using “pharmaceutical” POCIS}

3

5

6

\section{Nicolas Morin ${ }^{\mathrm{a}, \dagger}$, Julien Camilleri ${ }^{\mathrm{b}, \dagger}$, Cécile Cren-Olivéb, Marina Coquery ${ }^{\mathrm{a}}$, Cécile Miège $^{\mathrm{a},{ }^{*}}$}

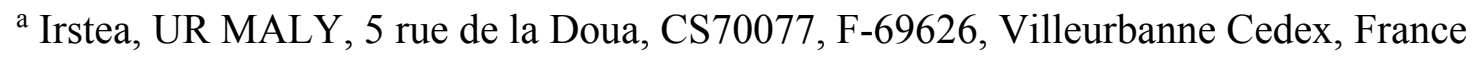

b UMR 5280 ISA, Département Service Central d'Analyse du CNRS-USR59, Université Lyon 1, ENS Lyon, 5 rue de la Doua, 69100 Villeurbanne, France

${ }^{\dagger}$ Both authors contributed equally to this work

* Corresponding author. Tel.: +33 (0)4 722087 44; Fax: +33 (0)4 784778 75; e-mail: cecile.miege@irstea.fr

\section{Abstract}

The literature increasingly reports sampling rates $\left(\mathrm{R}_{\mathrm{s}}\right)$ for Polar Organic Chemical Integrative Samplers (POCIS) but the data obtained come from various calibration systems that are not always well-defined (agitation, temperature, measured micropollutant concentrations in water,...). In order to obtain accurate laboratory $R_{S}$ for priority and emerging substances, POCIS need to be exposed in a robust and well-defined calibration system. Thus, we built a flow-through calibration system containing tap water spiked with 56 organic micropollutants (alkylphenols and phenols, hormones, pesticides, pharmaceuticals, UV filter). POCIS were immersed for up to 28 days. Tap water micropollutant concentrations and additional parameters (temperature, $\mathrm{pH}$, conductivity, dissolved organic carbon, flow velocities) were kept constant and controlled throughout the calibration experiment. Based on the observed uptake kinetics, we distinguished 4 types of micropollutant accumulation patterns: curvilinear accumulation (30 molecules, group 1), accumulation with an inflexion point (13 molecules, group 2), random accumulation (8 molecules, group 3), and no or very low accumulation (5 molecules, group 4). $\mathrm{R}_{\mathrm{s}}$ was calculated for 43 out of 56 micropollutants (groups 1 and 2). Calculated $R_{s}$ values ranged from $0.030 \mathrm{~L} / \mathrm{d}$ to $0.398 \mathrm{~L} / \mathrm{d}$. POCIS can supply TWA 
concentrations for hormones, pesticides, several pharmaceuticals, a few alkylphenols, and the UV filter. Our $\mathrm{R}_{\mathrm{s}}$ results are generally less than 2 fold-different (higher or lower depending on target molecule) to the literature data using the same type of calibration system or for micropollutants with $\log \mathrm{K}_{\mathrm{ow}}>2.65$. We found a quadratic correlation between $\mathrm{R}_{\mathrm{s}}$ and $\log \mathrm{D}$ for betablockers, herbicides and hormones.

Keywords: POCIS; sampling rates; uptake kinetics; calibration system; priority and emerging substances.

Abbreviations: $\mathrm{CF}$, concentration factor; DOC, dissolved organic carbon; DT, degradation time; LC, liquid chromatography; MRM, multiple reaction monitoring; MS, mass spectrometry; POCIS, polar organic chemical integrative sampler; PES, polyethersulfone; $\mathrm{PRC}$, performance and reference compound; PTFE, polytetrafluoroethylene; $\mathrm{R}_{\mathrm{s}}$, sampling rate; RSD, relative standard deviation; SPE, solid-phase extraction; TWA, time-weighted average.

\section{Introduction}

Integrative samplers such as the Polar Organic Chemical Integrative Sampler (POCIS) were designed to sample hydrophilic micropollutants [1]. They are immersed for a few days to a few weeks (14 days is a common standard), and accumulate compounds by passive diffusion. They can thus be used for screening with limits of detection that are often better than classic grab sampling since they are able to directly extract micropollutants in situ for several days. POCIS are also claimed to give time-weighted average (TWA) micropollutant concentrations in water over the immersion duration by using accurate sampling rates $\left(R_{S}\right)$. $R_{S}$ are dependent on environmental parameters such as agitation, temperature or biofouling [2]. TWA concentrations can be produced with in situ $\mathrm{R}_{\mathrm{s}}$ but the process entails performing an infield calibration for each campaign, making it a heavily time-intensive method [3], and the micropollutants have to be present in the aquatic system at a relatively constant concentration. Another method to determine TWA concentrations is to calibrate the POCIS in-lab. The huge advantage of this method is that it only has to be performed once and it allows controlling micropollutant concentrations. However, the drawback is the necessity to correct the in-lab $\mathrm{R}_{\mathrm{S}}$ that does not account for the effect of environmental conditions and can thus lead to biased in 
situ TWA concentrations [4]. This correction is made using internal surrogates, i.e. performance and reference compounds (PRCs), which are currently difficult to identify for POCIS [5].

In order to obtain accurate laboratory $\mathrm{R}_{\mathrm{s}}$, it is necessary to have a reliable, robust and well-defined calibration system. Literature reports do not always detail certain aspects of calibration and calculation, giving at best only partial information on POCIS (type and mass of receiving phase, exposed surface), calibration system (zero, discrete or continuous micropollutant renewal, exposure duration, design of the exposure system, container type, agitation type, physical-chemical parameters, and analyte concentration in the water) or sampling rate calculation method. Furthermore, it is also necessary to control key parameters (temperature, flow velocity, $\mathrm{pH}$, conductivity, dissolved organic carbon (DOC), tap water micropollutant concentrations) and to detail these controls [6]. Today, numerous references give laboratory $\mathrm{R}_{\mathrm{s}}$ with POCIS for micropollutants such as alkylphenols, hormones, pesticides or pharmaceuticals $[2,4-5,7-18]$. But given that lab calibration methods are not performed in the same way nor in a well defined way, $\mathrm{R}_{\mathrm{S}}$ could vary widely for a given micropollutant, making it difficult to select a reliable $\mathrm{R}_{\mathrm{s}}$ as benchmark.

Here, we report results on kinetic accumulations for 56 priority and emerging micropollutants ( 8 alkylphenols, 9 hormones, 11 pesticides, 27 pharmaceuticals and $1 \mathrm{UV}$ filter). More specifically, we identify molecules that fit or fail to fit the curvilinear model [1] and go on to discuss $\mathrm{R}_{\mathrm{S}}$ calculation method according to molecule. We also give well-defined laboratory $\mathrm{R}_{\mathrm{s}}$ produced with the "pharmaceutical" POCIS for 43 micropollutants. All aspects potentially influencing $\mathrm{R}_{\mathrm{s}}$ are detailed (i.e. POCIS and calibration system used, characteristics of the exposure media and sampling rate calculation method). We also discuss the validity field of the POCIS according to target micropollutant (concentration factor, optimal exposure duration, possibility for calculating TWA concentrations). We compared our results (accumulation kinetics and $\mathrm{R}_{\mathrm{s}}$ ) with the literature and studied the influence of $\log \mathrm{D}$ on $\mathrm{R}_{\mathrm{s}}$.

\section{Material and methods}

\subsection{Chemicals, material and apparatus}


Acetonitrile HiPerSolv Chromanorm, Acetonitrile LC/MS HiPerSolv Chromanorm, Dichloromethane HiPerSolv Chromanorm and Methanol HiPerSolv Chromanorm were purchased from VWR (Fontenay-sous-Bois, France). Ultrapure water was obtained on a MilliQ ${ }^{\circledR}$ Advantage A10 system equipped with an LC-Pak cartridge and a $0.22 \mu \mathrm{m}$ filter Millipak® 40 from Merck-Millipore (Saint-Quentin-en-Yvelines, France). Acetonitrile Chromasolv grade, Acetonitrile LC/MS Chromasolv grade, methanol Chromasolv grade, ammonium acetate puriss p.a. for mass spectroscopy $\geq 99.0 \%$, formic acid puriss p.a. eluent additive for $\mathrm{LC}-\mathrm{MS} \approx 98 \%$, Ammonium formiate puriss p.a. $\geq 99.0 \%$ and acetic acid puriss p.a. $\geq 99.8 \%$ were purchased from Fluka (Saint-Quentin-Fallavier, France).

The majority of analytical standards were purchased from Sigma-Aldrich (SaintQuentin-Fallavier, France), i.e. 7 alkylphenols and phenols (bisphenol A [BPA], t-butylphenol [t-BP], n-nonylphenol [n-NP], t-nonylphenol [t-NP], n-octylphenol [n-OP], t-octylphenol [tOP], resorcinol [Res]), 27 pharmaceuticals including 5 antibiotics (metronidazole [Metro], ofloxacin [Oflo], roxithromycin [Roxi], sulfamethoxazole [Sulfa], trimethoprim [Trim]), 5 anti-inflammatories (diclofenac sodium salt [Diclof], ibuprofen [Ibu], ketoprofen [Keto], naproxen [Napro], salicylic acid [SalA]), 2 benzodiazepines (lorazepam [Lora], oxazepam [Oxa]), 10 betablockers (acebutolol hydrochloride [Ace], atenolol [Ate], betaxolol [Bet], bisoprolol fumarate [Bis], metoprolol tartrate [Met], nadolol [Nad], oxprenolol [Oxp], propranolol hydrochloride [Prop], sotalol hydrochloride [Sot], timolol hydrogen maleate [Tim]), 2 lipopenics (bezafibrate [Beza], fenofibrate [Feno]) and 3 other pharmaceuticals (carbamazepine [Carba], furosemide [Furo], paracetamol [Para]), 11 pesticides including 4 fungicides (carbendazim [Carb], iprodione [Ipr], prochloraz [Pro], thiram [Thi]) and 7 herbicides (2.4-dichlorophenoxyacetic acid [2.4-D], 3.4-dichloroaniline [3.4-D], acetochlore [Acet], alachlore [Ala], atrazine [Atra], diuron [Diu], linuron [Lin]], 10 hormones including 5 estrogens (estrone [E1], 17 $\alpha$-estradiol [ $\alpha$-E2], 17 $\beta$-estradiol [ $\beta$-E2], estriol [E3], ethinylestradiol [EE2]), 2 progestogens (megestrol acetate [MegA], progesterone [P]), 1 androgen (testosterone [T]) and 1 anticancer drugs (tamoxifen [Tamo]) and 1 UV filter (4methylbenzylidene camphor [4-MBC]). One micropollutant (2.4-dichlorophenol-d3 [2.4DCP]) and one internal standard (17 $\beta$-estradiol acetate) were purchased from CIL (SainteFoy-La-Grande, France). The internal standard for betablockers (metoprolol impurity A) was purchased from LGC (Molsheim, France).

The POCIS was built using Oasis ${ }^{\circledR}$ HLB bulk sorbent (average particle diameter: 60 $\mu \mathrm{m})$ and hydrophilic polyethersulfone (PES) SUPOR 100 membrane disc filters $(0.1 \mu \mathrm{m}, 90$ $\mathrm{mm}$ membrane diameter) purchased from Waters (Guyancourt, France) and Pall (Saint- 
130 Germain-en-Laye, France), respectively. Empty glass solid phase extraction (SPE) tubes (6 $\mathrm{mL}$ ) and polytetrafluoroethylene (PTFE) frits (20 $\mu \mathrm{m}$ porosity) were purchased from Sodipro (Echirolles, France). The calibration system was composed of a Harvard Type 22 syringe pump from Harvard Apparatus (Les Ulis, France) and a Ismatec model Ecoline VC-MS/CA86 peristaltic pump from Thermofisher (Illkirch, France).

The chromatographic separation of 10 betablockers and 5 estrogens ([E1], $[\alpha-E 2],[\beta-$ E2], [E3], [EE2]) was performed with Xbridge C18 end-capped columns $(150 \times 2.1 \mathrm{~mm}, 3.5$ $\mu \mathrm{m})$ from Waters (Guyancourt, France) equipped with guard columns. The separations of the 41 remaining molecules were performed with a Kinetex XB-C18 Core Shell $(100 \times 2.1 \mathrm{~mm}$, $1.7 \mu \mathrm{m})$ equipped with a KrudKatcher $(0.2 \mu \mathrm{m})$ filter from Phenomenex (Le Pecq, France).

The liquid chromatography-mass spectrometry (LC-MS) system used for the analysis of 10 betablockers and 5 estrogens was composed of an Agilent 1100 chromatographic system from Agilent (Massy, France) coupled with an API 4000 triple-quadrupole mass spectrometer from AB Sciex (Les Ulis, France). The LC-MS system used for the analysis of the 41 remaining molecules was an Agilent 1200 chromatographic system from Agilent (Massy,

\subsection{Calibration design and POCIS exposure}

The calibration system is schematized in Figure 1. It consisted of 2 aquaria (up to $50 \mathrm{~L}$ ) filled by tap water freshly spiked at a nominal value of $3 \mu \mathrm{g} / \mathrm{L}$ for each analyte. This concentration permitted to analyze grab samples by direct injections in LC-MS and thus to easily control this parameter throughout the calibration phase. Triplicates of "pharmaceutical" POCIS (45.8 $\mathrm{cm}^{2}$ of exposed surface, $200 \mathrm{mg}$ of receiving phase) were immersed for $\mathrm{t}=1,3$, 6 and 12 hours and for $\mathrm{t}=1,3,7,14,21$ and 28 days. Given that we worked with 2 aquaria with a limited number of POCIS per aquarium and that each exposure duration was tested in triplicate, the total experiment duration was 42 days. In order to closely mimic the agitation conditions found in aquatic rivers, each POCIS was exposed to a current of around $10 \mathrm{~cm} / \mathrm{s}$ delivered perpendicularly to their surface by a diffusion ramp linked to a submersible pump. This set-up was inspired by the system developed by Mazzella et al. [10]. Tap water was thermostated at around $20^{\circ} \mathrm{C}$ by thermostated water-bath using an external thermostated tank. The system was kept in the dark to prevent any photolysis of analytes. 
The whole system was a flow-through calibration system, since freshly-spiked tap water was delivered continuously into each aquarium by a peristaltic pump and the excess was evacuated via an overflow (and sent through a $10 \mathrm{~g}$ activated carbon column for clean-up). Unspiked tap water was contaminated with 2 contaminant solutions (around $100 \mathrm{mg} / \mathrm{L}$ each, replaced every week) syringe-pumped into a mixing vessel (which was agitated with a

\section{3. $\quad$ POCIS and water sample pre-treatment and analysis}


The POCIS were home-made, with $200 \mathrm{mg}$ ( $\pm 5 \mathrm{mg}$ ) of receiving Oasis ${ }^{\circledR}$ HLB phase sandwiched between 2 PES membranes. This device set-up was kept between 2 stainless steel rings linked together by screws and nuts. The home-made POCIS were then stored at $5^{\circ} \mathrm{C}( \pm$ $1^{\circ} \mathrm{C}$ ) until immersion in the aquaria. During exposure, the POCIS were placed facing the flow coming from the diffusion ramp. After retrieval, the POCIS membranes were rinsed with a few $\mathrm{mL}$ of unspiked tap water, and the POCIS were then stored at $-23^{\circ} \mathrm{C}\left( \pm 3^{\circ} \mathrm{C}\right)$ until extraction. An additional blank POCIS, consisting in a POCIS not immersed in the exposure media was produced in order to check for any contamination of the receiving phase. This blank POCIS was stored at $-23^{\circ} \mathrm{C}\left( \pm 3^{\circ} \mathrm{C}\right)$ until processing.

\subsubsection{Treatment of POCIS before analysis}

Exposed POCIS and blank were left at ambient temperature for $1 \mathrm{hr}$ before processing. The POCIS were then disassembled and the sorbent was transferred with a few $\mathrm{mL}$ of ultrapure water under low vacuum in pre-weighed $6 \mathrm{~mL}$ glass SPE cartridges equipped with PTFE frits. The sorbent was dried under vacuum, and the micropollutants were eluted with 2 x $5 \mathrm{~mL}$ of methanol and then 2 x $5 \mathrm{~mL}$ of a methanol/dichloromethane mixture $(50 / 50, \mathrm{v} / \mathrm{v})$. Sorbent was dried again and weighed in order to measure the exact mass analyzed. Each eluate was separated into 3 fractions in order to quantify all micropollutants via 4 analytical methods (one fraction for betablockers analysis, one fraction for estrogen analysis, one fraction for 2 multiresidue analyses on the remaining molecules). The eluates were evaporated to dryness under a gentle stream of $\mathrm{N}_{2}$, and the extracts were then reconstituted into:

- $500 \mu \mathrm{L}$ of a $\mathrm{H}_{2} \mathrm{O} / \mathrm{ACN}$ mixture $(99 / 1, \mathrm{v} / \mathrm{v})$ and $50 \mu \mathrm{g} / \mathrm{L}$ of an internal standard (i.e. metoprolol impurity A) for betablocker analysis,

- $500 \mu \mathrm{L}$ of a $\mathrm{H}_{2} \mathrm{O} / \mathrm{ACN}$ mixture $(60 / 40, \mathrm{v} / \mathrm{v})$ and $50 \mu \mathrm{g} / \mathrm{L}$ of an internal standard (i.e. estradiol acetate) for estrogen analysis,

- $2 \mathrm{~mL}$ of a $\mathrm{H}_{2} \mathrm{O} / \mathrm{ACN}$ mixture (80/20, v/v) for the 2 multiresidue analyses.

Before analysis, extracts were diluted 100 to 500 times in order to be within the concentration range of each method and to guard against matrix effects. For betablocker and hormone analyses, dilutions were done in their respective mobile phase mixtures. For multiresidue analyses, extracts were diluted in ultrapure water. All extracts were stored at $23^{\circ} \mathrm{C}\left( \pm 3^{\circ} \mathrm{C}\right)$ until analysis. 
2.3.3. Treatment of water samples before analysis

The relatively high concentrations of micropollutants in spiked tap water (i.e. around 3 $\mu \mathrm{g} / \mathrm{L})$ made it possible to analyze water samples by direct injection in the chromatographic system after moderate dilution to obtain the adequate mobile phase mixture (i.e. $\mathrm{H}_{2} \mathrm{O} / \mathrm{ACN}$ $(99 / 1, v / v)$ for betablockers, $\mathrm{H}_{2} \mathrm{O} / \mathrm{ACN}(60 / 40$, v/v) for estrogens, and ultrapure water only for multiresidue analyses) and after adding possible internal standards (metoprolol impurity A and estradiol acetate at $50 \mu \mathrm{g} / \mathrm{L}$ for betablocker and estrogen analyses, respectively). Water samples were kept at $-23^{\circ} \mathrm{C}\left( \pm 3^{\circ} \mathrm{C}\right)$ until analysis.

\subsubsection{LC-MS/MS analysis}

The methods used for betablockers and estrogens are detailed elsewhere [19-20]. Briefly, chromatographic separation was performed with Xbridge C18 end-capped columns $(150 \times 2.1 \mathrm{~mm}, 3.5 \mu \mathrm{m})$ equipped with guard columns. Vials were kept at $4^{\circ} \mathrm{C}$ during analysis. Injected volumes were $10 \mu \mathrm{L}$. Column oven temperature was set at $28^{\circ} \mathrm{C}$ for betablockers and $30^{\circ} \mathrm{C}$ for estrogens. Gradients with LC-MS-grade water (buffered with ammonium formiate for betablockers) and acetonitrile were applied at a flow rate of 0.2 $\mathrm{mL} / \mathrm{min}$ : from $1 \% \mathrm{ACN}$ at 0 to 5 min ramped up to $100 \% \mathrm{ACN}$ at $21 \mathrm{~min}$ until $29 \mathrm{~min}$ for betablockers, and $40 \% \mathrm{ACN}$ from 0 to $2 \mathrm{~min}$ ramped up to $80 \% \mathrm{ACN}$ at $4.5 \mathrm{~min}$ until $7 \mathrm{~min}$ and up to $100 \% \mathrm{ACN}$ at $8.25 \mathrm{~min}$ until $15 \mathrm{~min}$ for estrogens. Separations were achieved in less than $20 \mathrm{~min}$ and $12 \mathrm{~min}$ for betablockers and estrogens, respectively.

Ionization was performed with an electrospray source in positive mode for betablockers and negative mode for estrogens. Acquisitions were performed in multiple reaction monitoring (MRM) mode. Detection included 2 ionization transitions for each analyte - one for quantification and the other for confirmation. The instrumental limits of quantification (direct injection) were $100 \mathrm{ng} / \mathrm{L}$ for betablockers and 150-700 $\mathrm{ng} / \mathrm{L}$ for estrogens depending on analyte micropollutant.

The multiresidue methods used for the 41 other micropollutants are detailed elsewhere [21]. Briefly, the chromatographic column used for separation was a Kinetex XB-C18 Core Shell $(100 \times 2.1 \mathrm{~mm}, 1.7 \mu \mathrm{m})$ equipped with a KrudKatcher $(0.2 \mu \mathrm{m})$ filter. Vials were kept at ambient temperature until analysis and injection volumes were $100 \mu \mathrm{L}$. Column oven 
temperature was $60^{\circ} \mathrm{C}$ for both ionization modes. In positive mode, the separation, achieved in 9 min, was performed with a multi-linear gradient with water (acidified with formic acid) and ACN. In negative mode, the separation, achieved in 7 min, was done with a multistep gradient with $0.1 \mathrm{mM}$ ammonium acetate in water and $\mathrm{ACN}$.

The mass spectrometer source was an electrospray in positive mode for 29 molecules: the UV filter, the hormones (other than estrogens), all the pesticides except 2.4dichlorophenoxyacetic acid and almost all pharmaceuticals except furosemide, ibuprofen and salicylic acid. The source was in negative mode for 12 molecules: all alkylphenols and phenols, 1 pesticide (2.4-dichlorophenoxyacetic acid) and 3 pharmaceuticals (furosemide, ibuprofen and salicylic acid). Acquisitions were performed in scheduled MRM and MRM mode for positive and negative modes, respectively. Two ionization transitions were used for each analyte (except for linear alkylphenols and 2.4-dichlorophenoxyacetic acid for which only one transition was possible) - one for quantification and one for confirmation. The instrumental limits of quantification (direct injection) varied from $1 \mathrm{ng} / \mathrm{L}$ for carbendazim to $579 \mathrm{ng} / \mathrm{L}$ for 2.4-diclorophenol.

\subsection{Sampling rate calculation methods}

Theoretically, it is possible to model the accumulation of micropollutants in the receiving phase of the POCIS by 3 successive accumulation regimes (as a function of time): a linear (or kinetic/integrative) regime, a pseudolinear regime, and an equilibrium regime [1]. If exchange is isotropic, this accumulation follows a first-order kinetic, which can be described by the equation (1):

$$
C_{s}=C_{w} \frac{k_{u}}{k_{e}}\left(1-e^{-k_{e} t}\right)
$$

where $C_{s}$ is the concentration of a given micropollutant in the sorbent at time $t(\mu \mathrm{g} / g), C_{w}$ the TWA concentration of the same micropollutant in the water $(\mu \mathrm{g} / \mathrm{L}), \mathrm{k}_{\mathrm{u}}$ the uptake rate constant of the micropollutant on the receiving phase $(\mathrm{L} / \mathrm{g} / \mathrm{d}), \mathrm{k}_{\mathrm{e}}$ the elimination (or exchange) rate constant of the micropollutant from the receiving phase $\left(\mathrm{d}^{-1}\right)$, and $\mathrm{t}$ the time $(\mathrm{d})$.

POCIS is generally used in the linear regime to lead to TWA concentrations. In this regime, the sampler acts as an "infinite sink", and $\mathrm{k}_{\mathrm{e}}$ is negligible compared to $\mathrm{k}_{\mathrm{u}}$. It is therefore possible to simplify the equation (1) and to link the concentration quantified in the 


\subsection{A reliable calibration system} [2]: follows: equation (4): neutralize the effect of $\mathrm{C}_{\mathrm{w}}$ variations. the standard deviation of the Rs.

\section{Results and discussion}

POCIS to its concentration in the sampling medium via the sampling rate, using equation (2)

$$
C_{s}=\frac{C_{w} R_{s} t}{M_{s}}
$$

where $R_{s}$ is the sampling rate $(L / d)$, and $M_{s}$ the mass of sorbent in the POCIS (g).

The frontier between the kinetic regime and the pseudolinear regime corresponds to $t_{1 / 2}$, i.e. the time necessary to reach half of the equilibrium concentration [5]. Thus, $\mathrm{R}_{\mathrm{s}}$ must be calculated during a period shorter than or equal to $t_{1 / 2}$ in order to be accurate. $t_{1 / 2}$ is defined as

$$
t_{1 / 2}=\frac{\ln 2}{k_{e}}
$$

Rewriting equation (2), it is possible to tease out the concentration factor, as indicated in

$$
C F=\frac{C_{s}}{C_{w}}=\frac{R_{s} t}{M_{s}}
$$

where $\mathrm{CF}$ is the concentration factor $(\mathrm{L} / \mathrm{g})$. The concentration factor makes it possible to

In this paper, we used equation (4) until the $t_{1 / 2}$ of each micropollutant in order to calculate $\mathrm{R}_{\mathrm{s}}$. First of all, we drew $\mathrm{CF}$ as a function of time (using $\mathrm{C}_{\mathrm{s}}$ and $\mathrm{C}_{\mathrm{w}}$ quantified at each POCIS removal time). Then, the curve obtained made it possible to determine the $\mathrm{k}_{\mathrm{e}}$ and thus the $t_{1 / 2}$ for each micropollutant using XLStat software. We thus obtained a line whose slope was equal to $R_{S} / M_{s}$. We calculated accurate $R_{s}$ using this slope multiplied by the mean of POCIS masses exposed until $\mathrm{t}_{1 / 2}$. The standard deviation of the slope was used to determine 
Additional parameters and flow velocities were followed and kept constant during the 42 days experiment duration, as reported in Table 1. Indeed, the RSDs for these parameters never exceeded $27 \%$. During the whole period of the calibration phase, temperature was around $21^{\circ} \mathrm{C}, \mathrm{pH}$ was around 7.6 , conductivity was around $430 \mu \mathrm{S} / \mathrm{cm}$, DOC was around 10 $\mathrm{mg} / \mathrm{L}$, and the flow velocities had a mean value of $11 \mathrm{~cm} / \mathrm{s}$.

Insert Table 1

Figure 2 represents the mean of spiked tap water concentration of the 56 organic micropollutants over the course of 42-day experiment in both aquaria.

Insert Figure 2

Out of the 56 molecules tested, 44 had a mean of spiked tap water concentration close to the nominal value $(3 \pm 2 \mu \mathrm{g} / \mathrm{L})$. Among the 12 remaining molecules, 8 are known to degrade in water under our renewal conditions (as proved in a previous experiment), which explains why their concentrations were too low (i.e. n-octylphenol, n-nonylphenol, salicylic acid, fenofibrate, iprodione, thiram with concentrations $<1 \mu \mathrm{g} / \mathrm{L}$ ) or dispersed (i.e. tamoxifen: 5.1 $\pm 3.4 \mu \mathrm{g} / \mathrm{L}$ ). The eighth molecule, t-octylphenol, should also be degraded (according to the degradation test) but in this experiment, its concentration was higher than expected (17.0 $\mu \mathrm{g} / \mathrm{L})$. Among the final 4 remaining molecules, 3 had higher mean concentrations than expected (2.4-dichlorophenol: $7.1 \mu \mathrm{g} / \mathrm{L}$, ofloxacin: $8 \mu \mathrm{g} / \mathrm{L}$ and roxithromycin: $18.5 \mu \mathrm{g} / \mathrm{L}$ ) and 1 had a lower mean concentration than expected (resorcinol: $0.4 \mu \mathrm{g} / \mathrm{L}$ ). This may be due to biodegradation process for resorcinol [22] and possible matrix effects in water concentrations for t-octylphenol, 2.4-dichlorophenol, ofloxacin and roxithromycin. Either way, ruling out molecules degraded in tap water and resorcinol due of its very low mean water concentration $(0.4 \mu \mathrm{g} / \mathrm{L})$, the relative standard deviation (RSD) never exceeded $47 \%$ (t-butylphenol and progesterone) and was lower than $35 \%$ for all the other molecules, which is very satisfying considering the long 42-day duration of the calibration experiment.

$\mathrm{R}_{\mathrm{s}}$ were not calculated for micropollutants with tap water concentrations far from the nominal value (lower than $1 \mu \mathrm{g} / \mathrm{L}$ or higher than $5 \mu \mathrm{g} / \mathrm{L}$ ) or with high RSD (above 35\%), except for 2.4-dichlorophenol and t-octylphenol (water concentrations of $7.1 \mu \mathrm{g} / \mathrm{L}$ and 17.0 $\mu / L$ respectively; detailed data shown in supplementary material), and for t-butylphenol, progesterone, 4-methylbenzylidene camphor (random water concentration variations leading 
to RSDs of $46-47 \%$; detailed data shown in supplementary material) for which the calculated

360 CFs lead to well-defined $\mathrm{R}_{\mathrm{s}}$. Nonetheless, for 2.4-dichlorophenol and t-octylphenol, $\mathrm{R}_{\mathrm{s}}$ are given for information and still need to be validated.

The supplementary material (S1) reports spiked tap water concentrations for 9 micropollutants (4 with concentrations close to the nominal value: ethinylestradiol, metoprolol, bisphenol A and linuron; 2 with concentrations far from the nominal value: 2.4dichlorophenol and t-octylphenol; 3 with concentration variations higher than $35 \%$ over the entire experiment duration: t-butylphenol, progesterone and 4-methylbenzylidene camphor).

Allowing for small variations, our calibration system makes it possible to keep constant additional parameters, flow velocities, and waters concentrations of most of the micropollutants, thus enabling the calculation of well-defined $\mathrm{R}_{\mathrm{s}}$.

\subsection{Accumulation kinetics}

This section discusses the accumulation kinetics curves obtained for the 56 micropollutants for 28 days exposure. These curves enabled us to show the behaviour of each micropollutant in the POCIS receiving phase and, when possible, to estimate $t_{1 / 2}$, which is rarely if ever indicated in the literature.

We distinguished 4 different groups:

- group 1, made up of 30 micropollutants showing curvilinear accumulation kinetics as described in the model from Alvarez [1] and equation (1),

- group 2, made up of 13 micropollutants having an inflexion point in their accumulation kinetics curve,

3883 illustrates the 4 different types of accumulation with two examples from each group. 389 Detailed accumulation curves for the 56 micropollutants can be found in the supplementary material. 
Table 2 compiles the key information on these micropollutants and indicates their physical-chemical properties, as discussed below.

Insert Figure 3

\subsubsection{Group 1: micropollutants with a curvilinear accumulation kinetics curve}

There were 30 micropollutants presenting a curvilinear accumulation kinetics curve and for which the POCIS can supply TWA concentrations as explained in equation (2). Group-1 micropollutants had $t_{1 / 2}$ from 5 to 693 days. They can be ionized or neutral, with $\log \mathrm{K}_{\mathrm{ow}}$ from 1.34 to 5.12 . Their molecular weights vary from 150.1 to $376.7 \mathrm{~g} / \mathrm{mol}$.

POCIS are generally exposed in the field for 14 days $[2,4,16]$. According to table 2 , we found a $t_{1 / 2}$ higher than or equal to 14 days with neutral micropollutants (20 over 21$)$ and lower than 14 days for ionized micropollutants ( 8 of 9 ). Moreover, micropollutants with $t_{1 / 2} \geq$ 14 days have a mean $\log \mathrm{K}_{\mathrm{ow}}$ of $3.5( \pm 0.8)$ whereas molecules with $\mathrm{t}_{1 / 2}<14$ days have a mean $\log \mathrm{K}_{\text {ow }}$ of $2.3( \pm 0.6)$. Molecular weight did not seem to have any influence on $\mathrm{t}_{1 / 2}$ duration. Indeed, molecules with $\mathrm{t}_{1 / 2} \geq 14$ days have a mean molecular weight of $272 \mathrm{~g} / \mathrm{mol}( \pm 52)$ while molecules with $\mathrm{t}_{1 / 2}<14$ days have a mean molecular weight of $267 \mathrm{~g} / \mathrm{mol}( \pm 68)$.

The $t_{1 / 2}$ calculation is a fairly delicate task since $t_{1 / 2}$ can change dramatically with a small variation in a kinetic point, but it remains a valuable criterion for providing the optimal exposure duration of POCIS. TWA water concentrations can be easily calculated from equation (2) for micropollutants with $t_{1 / 2} \geq 14$ days since they are linearly accumulated during classical in situ 14-day exposure durations. However, for the other group-1 molecules, POCIS should not have to be immersed higher than $t_{1 / 2}$ for rigorous TWA concentration calculations (i.e. 5 days for 2.4-DCP).

Lag times (between 3 hours and up to 3 days) were observed for 3.4-dichloroaniline,

419 linuron, 2.4-dichlorophenol, t-butylphenol, prochloraz, megestrol acetate, ethinylestradiol, 420 progesterone, estrone, t-octylphenol and 4-methylbenzylidene camphor. There was no clear 421 explanation for this phenomenon, but lag times were generally (but not systematically) 422 observed for neutral micropollutants or for $\log \mathrm{K}_{\mathrm{ow}}$ higher than 2.3. Lag times have already 423 been reported for prochloraz and 4-methylbenzylidene camphor on a C18 Chemcatcher using 
424 PES membranes [21]. These effects had no impact on calculated $\mathrm{R}_{\mathrm{s}}$ (except for 2.4425 dichlorophenol where $R_{s}$ is possibly underestimated) since $t_{1 / 2}$ micropollutants were 11 to 2772 times higher than the lag time duration for t-octylphenol and progesterone, respectively.

\subsubsection{Group 2: micropollutants with an inflexion point}

429

430

This group encompassed 13 micropollutants based on their higher accumulation rate in the POCIS during the first week of exposure leading to an inflexion point (generally at day 14) and their coefficients determined as lower than 0.99 compared to the curvilinear model (e.g. ketoprofen, figure 3.d. with $\mathrm{R}^{2}=0.98$ ). For these compounds, XLStat software miscalculated $t_{1 / 2}$ since the model was not curvilinear over 28 days. We thus recalculated $\mathrm{R}_{\mathrm{s}}$ with POCIS immersed at day 14 . We assumed that these $R_{s}$ were as accurate as those of group 1, since there was an integrative phase after the inflexion point. As was the case for group 1, POCIS can produce TWA concentrations for these micropollutants.

Group-2 micropollutants are generally in ionic form ( 9 out of 13; Table 2 ) in a log $\mathrm{K}_{\mathrm{ow}}$ range of between -0.40 and 3.99. Neutral molecules are relatively polar $\left(\log K_{\text {ow }} \leq 2.67\right)$. The higher accumulation rate up to 7 days may be explained by a burst effect $[1,10]$. This phenomenon is due to the time delay required for complete wetting of the POCIS membranes and can be avoided by pre-wetting the POCIS before immersion. These molecules might also accumulate in POCIS following two different sorption mechanisms, e.g. adsorption and then partitioning, or a multi-layer adsorption mirroring gas adsorption on a solid: a first layer directly on the sorbent and a second layer over the first layer [23].

\subsubsection{Group 3: micropollutants with random accumulation kinetics curves}

The 8 micropollutants forming group 3 were characterized by a random accumulation in the POCIS receiving phase with a concentration factor higher than 3. For these micropollutants, POCIS could not supply reliable TWA concentrations but can be used for screening. We supposed that this type of accumulation is not due to degradation in HLB phase because tests proved that pesticides (acetochlor, alachlor, atrazine, diuron, linuron, 2.4dichlorophenoxyacetic acid), pharmaceuticals (atenolol, carbamazepin, diclofenac, ibuprofen, ketoprofen, metoprolol, naproxen, propranolol, sulfamethoxazole, trimethoprim) and 
456 hormones (estrone, estriol, ethinylestradiol) adsorbed on it are well conserved during weeks to 457 months [24-25].

458 These micropollutants are polar or apolar ( $\log \mathrm{K}_{\mathrm{ow}}$ from 0.65 to 5.44$)$, neutral or ionized

459

460

461

462

463

464

465

466

467

468

469

470

471

472

473

474

475

476

477

478

479

480

481

482

483

484

485

486

487

in tap water at $\mathrm{pH}=7.6$. They include 6 pharmaceuticals, resorcinol, and t-nonylphenol.

These unpredictable accumulations make it impossible to reliably determine $t_{1 / 2}$. For all group-3 micropollutants, the RSDs of tap water concentrations were higher than $30 \%$, and 5 molecules (iprodione, t-nonylphenol, salicylic acid, thiram, fenofibrate) are known (from previous experiments) to degrade in tap water under our renewal conditions (degradation time 50 [DT50]: iprodione $<3 \mathrm{~d}$; thiram $<3.5 \mathrm{~d}$; salA $<6 \mathrm{~h}$; feno $<6 \mathrm{~h}$ ), which may explain some of the random accumulation curves.

\subsubsection{Group 4: micropollutants with low or no accumulation kinetics curve}

Five molecules were characterized by a very low or no accumulation in the POCIS receiving phase (Table 2). The POCIS is not designed to sample such micropollutants.

As with group 3 , these micropollutants can be polar or apolar ( $\log \mathrm{K}_{\mathrm{ow}}$ from -0.46 to 6.35), and neutral or ionized in tap water at $\mathrm{pH}=7.6$.

Four of these 5 micropollutants, RSDs of tap water concentrations were higher than $30 \%$, and three (n-octylphenol, n-nonylphenol and tamoxifen, DT50 $<3 \mathrm{~h}$ ) are known to degrade in tap water under our renewal conditions, which may explain their very low or no accumulation rates.

\subsubsection{Accumulation kinetics compared against the literature}

There are already literature reports of accumulation kinetics studied in-lab with "pharmaceutical" POCIS for 29 out of our 56 micropollutants of interest. However, the great majority of authors only show linear or curvilinear accumulation curves, notable exceptions being MacLeod et al. [7] and Harman et al. [13]. We cannot find any author taking time to discuss atypical accumulation (with inflexion point, random or low) and the consequences on $\mathrm{R}_{\mathrm{s}}$ calculation. For comparison, Table 3 reports kinetic curves data studied in the literature.

Insert Table 3 
The 17 group-1 micropollutants studied in the literature always showed linear accumulation, thus confirming our findings. Nevertheless, some of these micropollutants were exposed for only 8 days (t-butylphenol, metoprolol, propranolol and linuron) and their accumulations were drawn with only 4 samples, which is not enough to correctly estimate the $t_{1 / 2}$. It is important to have a lot of datapoints, especially at the beginning of the calibration, to be able to refine the line of the kinetics accumulation. MacLeod et al. [7], Harman et al. [13] and Martinez-Bueno et al. [16] reported nonlinear accumulation curves for a few micropollutants (from groups 2, 3 and 4, and including antibiotics and some alkylphenols) but did not discuss potential explanations for these atypical accumulation patterns nor the consequence on $\mathrm{R}_{\mathrm{s}}$ calculation. Finally, contrary to our results, MacLeod et al. [7], Li et al. [14] and Bartelt-Hunt et al. [11] all found linear kinetic accumulations for anti-inflammatories and betablockers. This divergence may be explained by their different calculation methods (measuring decreasing concentrations in water instead of increasing concentrations in POCIS) and calibration systems (beaker or bottle and distilled water).

\section{3. $\quad$ Sampling rates $\left(R_{s}\right)$}

505

One essential point for accurately calculating $R_{s}$ is to be in the kinetic regime of the POCIS. Thus, for group-1 molecules, we calculated $R_{s}$ using the slope of the line $C F=f(t)$ until their respective $t_{1 / 2}$, as explained in the experimental section. For group- 2 molecules, we calculated sampling rates at day 14 using equation [4], with a possible bias since the duration of the kinetic regime was not well-defined in this case. Note that it was not possible to calculate any sampling rates for group-3 or group- 4 molecules because they were randomly, poorly or not at all accumulated.

We compiled calculated $\mathrm{R}_{\mathrm{s}}$ in Table 4 and compared them against $\mathrm{R}_{\mathrm{s}}$ values reported in the literature when obtained with the same kind of POCIS ("pharmaceutical" POCIS with $45.8 \mathrm{~cm}^{2}$ surface and $200 \mathrm{mg}$ of receiving phase) and in the same conditions (under agitation and at between 15 and $25^{\circ} \mathrm{C}$ ). Sampling rates varied from $0.025 \mathrm{~L} / \mathrm{d}$ for atenolol up to 0.398 for t-butylphenol. Our study produced 16 laboratory $\mathrm{R}_{\mathrm{s}}$ now published for the first time here.

renst Table 4 
The POCIS is a useful tool for sampling herbicides, hormones, some alkylphenols, some pharmaceuticals like benzodiazepines, and the UV filter. Indeed, for these micropollutants (group 1), the kinetic regime is equal to or higher than 14 days, which is a comfortable duration for using the POCIS in situ to determine TWA concentrations. If the POCIS is immersed just for 7 days, it can be useful for betablockers with $\log \mathrm{K}_{\mathrm{ow}}>1.34$ ( $\mathrm{t}_{1 / 2}$ between 7 and 14 days; group 1). We assume that POCIS are suitable for some antibiotics, antiinflammatories, and hydrophilic betablockers with $\mathrm{R}_{\mathrm{s}}$ calculated from the triplicate at 14 days (group 2). For group-3 micropollutants, the POCIS is only suitable for screening. For group-4 molecules, the POCIS is simply not suitable.

Compared to the $\mathrm{R}_{\mathrm{s}}$ from authors using the same kind of calibration system (i.e. aquaria with a flow velocity arriving directly at the front of the POCIS; Mazzella et al. [10] and Lissalde et al. [15]), our $\mathrm{R}_{\mathrm{s}}$ values are generally less than 2-fold different. Our $\mathrm{R}_{\mathrm{s}}$ were also close (i.e. less than 2 fold-different) to reported values for hydrophobic molecules $\left(\log \mathrm{K}_{\mathrm{ow}}>\right.$ 2.65), except Li et al. [14] who obtained significantly higher $\mathrm{R}_{\mathrm{s}}$ than ours (or than those reported in the literature), including up to 11-fold higher values for sulfamethoxazole. As stated earlier, this can be explained by the different calculation method and calibration system used, which further underlines the critical need to define standardized protocols to obtain comparable sampling rates [6].

\subsection{Is it possible to predict $R_{s}$ from micropollutant physical-chemical} properties?

We found a quadratic correlation between $\mathrm{R}_{\mathrm{S}}$ and $\log \mathrm{D}$ for betablockers, herbicides and hormones, as illustrated in Figure 4. We used this parameter because it takes into account the hydrophobic-hydrophilic character $\left(\log \mathrm{K}_{\mathrm{ow}}\right)$ of a micropollutant as well as its potential charge (pKa). Other studies have also attempted to find correlations to explain $R_{s}$ values, but with $\log \mathrm{K}_{\text {ow }}$ and not $\log \mathrm{D}[8,10,26]$.

Insert Figure 4

Figure 4 shows increasing $\mathrm{R}_{\mathrm{s}}$ values as a function of $\log \mathrm{D}$ for betablockers, herbicides and hormones. However, the line of the curve is not the same for a given family, and reached a plateau for the betablockers $(\log \mathrm{D} 0.0-0.5)$, herbicides $(\log \mathrm{D} 2.5-3.5)$ and hormones $(\log \mathrm{D}$ 
3.5-4.5) families. The range of $\mathrm{R}_{\mathrm{S}}$ can be predicted as a function of $\log \mathrm{D}$ for some but not all micropollutants, which suggests that other physical-chemical properties also need to be considered.

\section{Conclusion}

We report a calibration experiment that is reliable and robust in terms of constant values for micropollutant concentrations in tap water, flow velocities and additional parameters (temperature, $\mathrm{pH}$, conductivity, dissolved organic carbon concentration). This system allowed us to study the accumulation of 56 organic micropollutants using the "pharmaceutical" POCIS for up to 28-day exposure periods. We distinguished 4 different types of accumulation curves: curvilinear (group 1), with inflexion point (group 2), random (group 3), and no or low accumulation (group 4). It was possible to calculate well-defined $\mathrm{R}_{\mathrm{S}}$ for 43 micropollutants, of which 16 are new $R_{s}$ published here for the first time. $R_{s}$ for these 43 micropollutants varied from 0.025 to $0.398 \mathrm{~L} / \mathrm{d}$. Nevertheless, the sampling rates of 2.4-dichlorophenol and toctylphenol have to be validated because of suspected matrix effects in tap water for both micropollutants and high lag time ( 3 days) coupled to short kinetic regime ( $\mathrm{t}_{1 / 2}=5$ days) for 2.4-dichlorophenol.

The POCIS is particularly suitable for sampling neutral micropollutants (included in group 1) with $\log \mathrm{K}_{\text {ow }}$ ranging from 2.5 to 5 , such as hormones, pesticides or several pharmaceuticals. Indeed, the kinetic regime for this type of molecule is higher than or equal to 14 days, which is suitable for in situ application of POCIS to evaluate TWA water concentrations. POCIS can also produce TWA concentrations for more hydrophilic (with log $\mathrm{K}_{\mathrm{ow}}$ as low as -0.34) and ionized micropollutants such as antibiotics, anti-inflammatories and betablockers (included in groups 1 and 2). However, POCIS is only suitable for screening for micropollutants with random accumulation (e.g. thiram, roxithromycin, group 3), and is not at all suitable for micropollutants with very low or no accumulation (e.g. metronidazole, tamoxifen, group 4).

To our knowledge, this is the first paper dealing with POCIS-derived accumulation curves with an inflexion point. There is a need to determine a model which better described this type of accumulation. Moreover, it would be interesting to better understand the underlying processes involved in POCIS accumulation of these micropollutants (large burst 
586 effect, two biphasic accumulation phenomena, multi-layer adsorption are candidates). 587 Analysis of the POCIS membranes could give clues.

588 Finally, it is difficult to predict $R_{s}$ as a function of the physical-chemical properties of 589 target molecules, except for betablockers, herbicides and hormones with $\log \mathrm{D}$. This point 590 should be a direction for further research. 


\section{Acknowledgements}

594

595 The authors thank the Cluster de Recherche Rhône-Alpes Environnement for financing

596 Nicolas Morin's thesis and the MEEDM (Ministère de l'Ecologie, de l'Environnement, du 597 Développement durable et de la Mer) for financing Julien Camilleri's thesis. We also thank 598 Ghislaine Grisot, Julie Iaciancio, Loïc Richard and Hélène Sanejouand for their valuable 599 support with analysis, and ATT for English language editing.

600

601 


\section{References}

604 [1] D.A. Alvarez, Development of an Integrative Sampling Device for Hydrophilic Organic 605 Contaminants in Aquatic Environments, University of Missouri-Columbia, Columbia, MO, 606 USA, 1999, 160.

607 [2] D.A. Alvarez, J.D. Petty, J.N. Huckins, T.L. Jones-Lepp, D.T. Getting, J.P. Goddard, S.E. 608 Manahan, Environ. Toxicol. Chem., 23 (2004) 1640-1648.

609 [3] R. Jacquet, C. Miège, P. Bados, S. Schiavone, M. Coquery, Environ. Toxicol. Chem., 31 $610 \quad$ (2012) 279-288.

611 [4] N. Mazzella, S. Lissalde, S. Moreira, F. Delmas, P. Mazellier, J.N. Huckins, Environ. Sci. 612 Technol., 44 (2010) 1713-1719.

613 [5] D.A. Alvarez, J.N. Huckins, J.D. Petty, T. Jones-Lepp, F. Stuer-Lauridsen, D.T. Getting, 614 J.P. Goddard, A. Gravell, Comprehensive Analytical Chemistry, in: Passive Sampling 615 Techniques in Environmental Monitoring, Elsevier, 2007, pp. 171-197.

616 [6] N. Morin, C. Miège, M. Coquery, J. Randon, TrAC - Trends in Analytical Chemistry, 617 (2012).

618 [7] S.L. MacLeod, E.L. McClure, C.S. Wong, Environ. Toxicol. Chem., 26 (2007) $2517-$ 6192529.

620 [8] A. Arditsoglou, D. Voutsa, Environ. Pollut., 156 (2008) 316-324.

621 [9] M.D. Hernando, M.J. Martínez-Bueno, A.R. Fernández-Alba, Boletin - Instituto Espanol 622 de Oceanografia, 21 (2005) 37-46.

623 [10] N. Mazzella, J.F. Dubernet, F. Delmas, J. Chromatogr. A, 1154 (2007) 42-51.

624 [11] S.L. Bartelt-Hunt, D.D. Snow, T. Damon-Powell, D.L. Brown, G. Prasai, M. Schwarz, 625 A.S. Kolok, Environ. Toxicol. Chem., 30 (2011) 1412-1420.

626 [12] C. Harman, O. Bøyum, K.V. Thomas, M. Grung, Environ. Toxicol. Chem., 28 (2009) $627 \quad 2324-2332$.

628 [13] C. Harman, K.E. Tollefsen, O. Bøyum, K. Thomas, M. Grung, Chemosphere, 72 (2008) 629 1510-1516.

630 [14] H. Li, P.A. Helm, C.D. Metcalfe, Environ. Toxicol. Chem., 29 (2010) 751-762.

631 [15] S. Lissalde, N. Mazzella, V. Fauvelle, F. Delmas, P. Mazellier, B. Legube, J. 632 Chromatogr. A, 1218 (2011) 1492-1502.

633 [16] M.J. Martínez Bueno, M.D. Hernando, A. Agüera, A.R. Fernández-Alba, Talanta, 77 634 (2009) 1518-1527.

635 [17] T. Rujiralai, I.D. Bull, N. Llewellyn, R.P. Evershed, J. Environ. Monitor., 13 (2011) $636 \quad 1427-1434$.

637 [18] Z. Zhang, A. Hibberd, J.L. Zhou, Anal. Chim. Acta, 607 (2008) 37-44.

638 [19] V. Gabet-Giraud, C. Miège, J.M. Choubert, S.M. Ruel, M. Coquery, Sci. Total Environ., $639408(2010) 4257-4269$.

640 [20] C. Miège, P. Bados, C. Brosse, M. Coquery, TrAC - Trends in Analytical Chemistry, 28 641 (2009) 237-244.

642 [21] J. Camilleri, N. Morin, C. Miège, M. Coquery, C. Cren-Olivé, J. Chromatogr. A, 1237 643 (2012) 37-45.

644 [22] http://www.speclab.com/compound/c108463.htm

645 [23] K.S.W. Sing, D.H. Everett, R.A.W. Haul, L. Moscou, R.A. Pierotti, J. Rouquerol, T. 646 Siemieniewska, Pure Appl. Chem., 57 (1985) 603-619.

647 [24] J.C. Carlson, J.K. Challis, M.L. Hanson, C.S. Wong, Environ. Toxicol. Chem., (2012).

648 [25] Applicabilité de solutions analytiques alternatives pour l'analyse de polluants organiques 649 
650 [26] A. Togola, H. Budzinski, Anal. Chem., 79 (2007) 6734-6741.

651 [27] C. Harman, O. Bøyum, K. Erik Tollefsen, K. Thomas, M. Grung, J. Environ. Monitor., $65210(2008) 239-247$.

653 [28] P. Matthiessen, D. Arnold, A.C. Johnson, T.J. Pepper, T.G. Pottinger, K.G.T. Pulman, 654 Sci. Total Environ., 367 (2006) 616-630.

655

656 


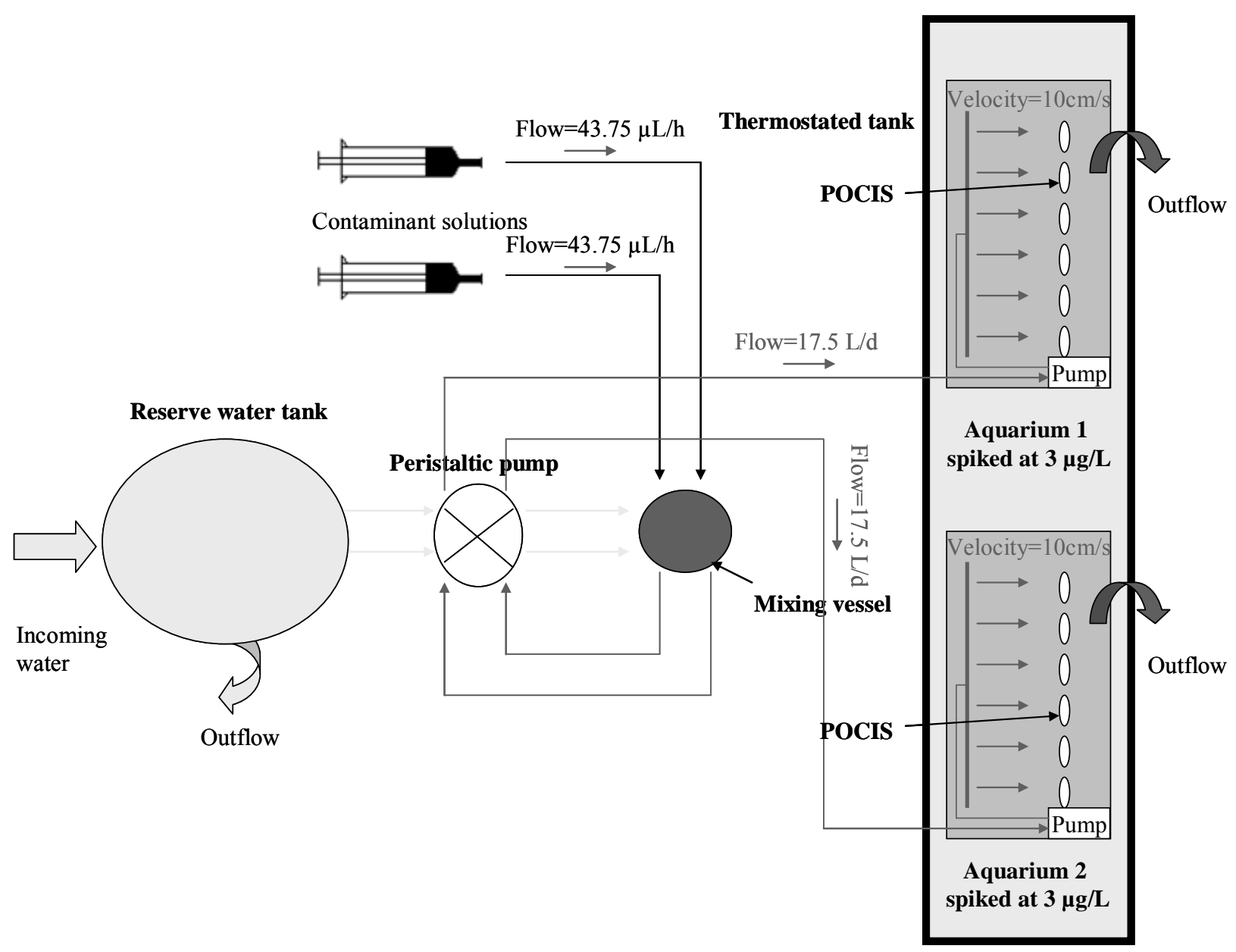

658 Fig. 1. Schematized flow-through calibration system for POCIS exposure. 


\section{Table 1}

662 Mean values for temperature, $\mathrm{pH}$, conductivity, DOC and flow velocity in the two aquaria, 663 and their associated variability (RSD).

664

\begin{tabular}{cccccc}
\hline & $\begin{array}{c}\text { Temperature } \\
\left({ }^{\circ} \mathrm{C}\right) \\
(\mathrm{n}=12)\end{array}$ & $\begin{array}{c}\mathrm{pH} \\
(\mathrm{n}=14)\end{array}$ & $\begin{array}{c}\text { Conductivity } \\
(\mu \mathrm{s} / \mathrm{cm}) \\
(\mathrm{n}=14)\end{array}$ & $\begin{array}{c}\text { DOC } \\
(\mathrm{mg} / \mathrm{L}) \\
(\mathrm{n}=12)\end{array}$ & $\begin{array}{c}\text { Flow velocity } \\
(\mathrm{cm} / \mathrm{s}) \\
(\mathrm{n}=63)\end{array}$ \\
\hline Mean & 20.7 & 7.6 & 429 & 10.1 & 11 \\
\hline RSD (\%) & 3 & 6 & 1 & 17 & 23 \\
\hline
\end{tabular}

665

666

667 


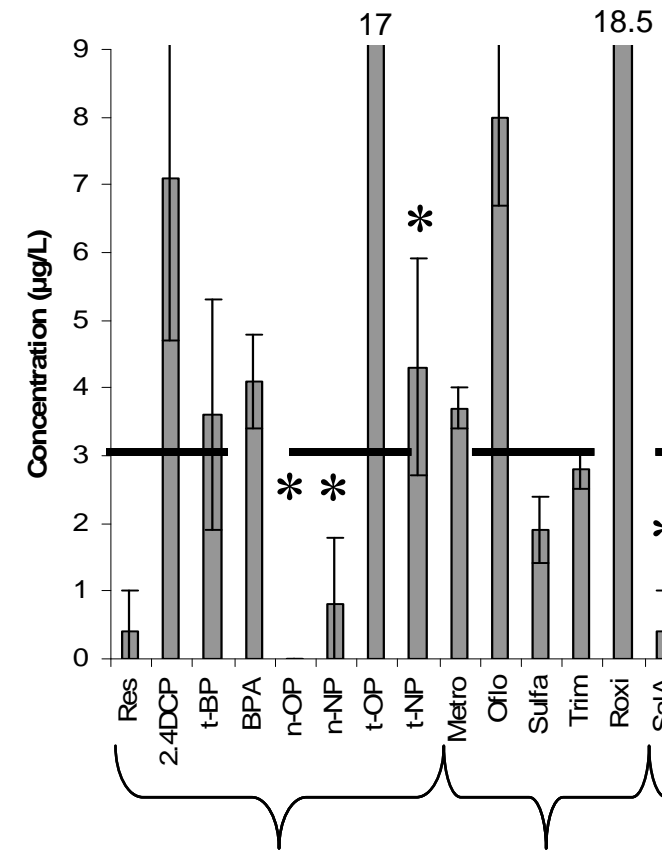

18.5

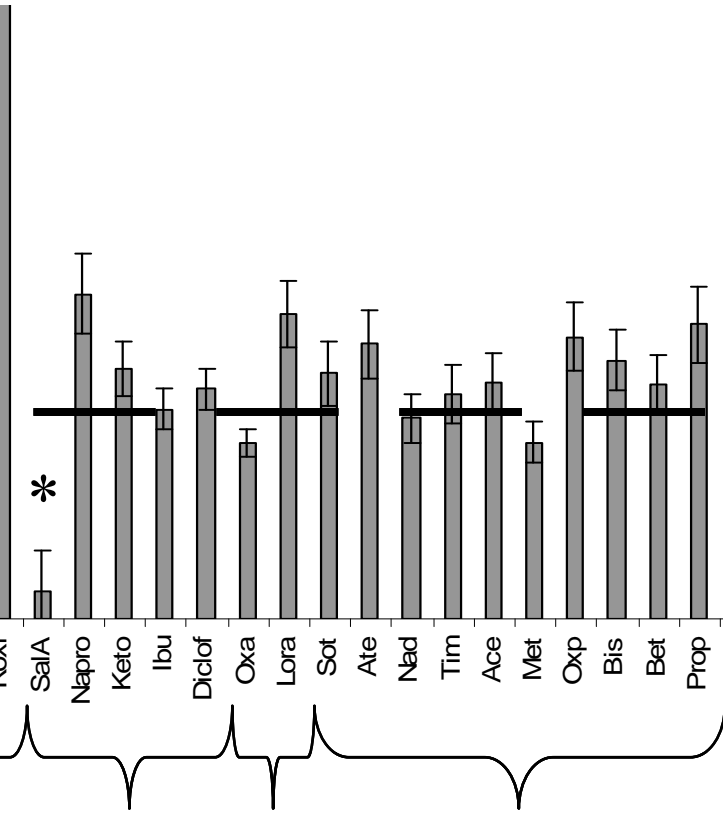

Betablockers

\section{Lipo. Other}

phar. Fungicides Herbicides

Hormones

filter

Fig. 2. Mean spiked tap water concentrations of the 56 studied micropollutants ( $n=74$ for betablockers and estrogens i.e. E1, $\alpha$-E2, $\beta$-E2, E3, 
a.

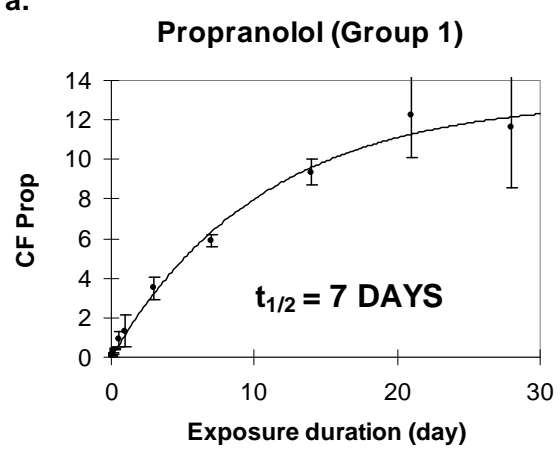

c.

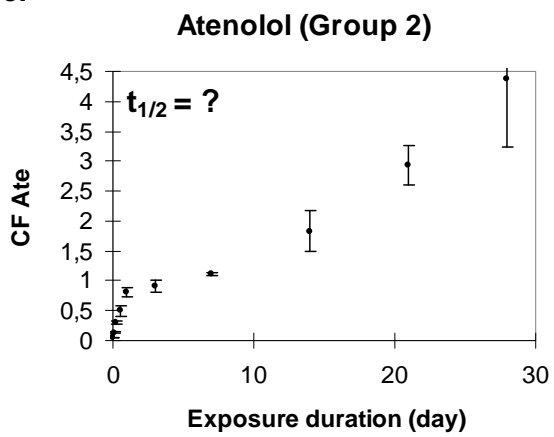

e.

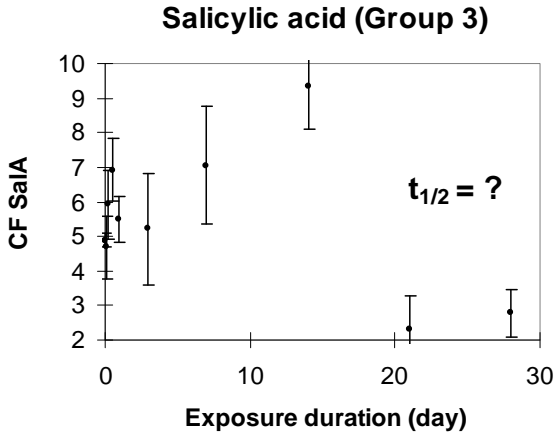

g.

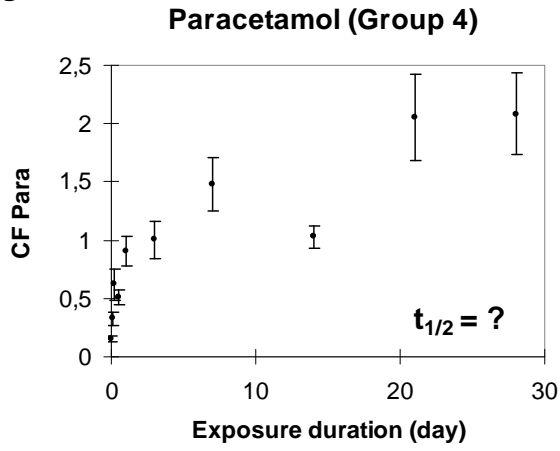

b.

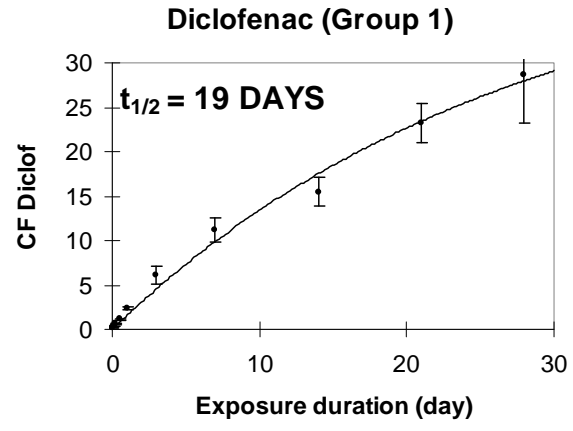

d.

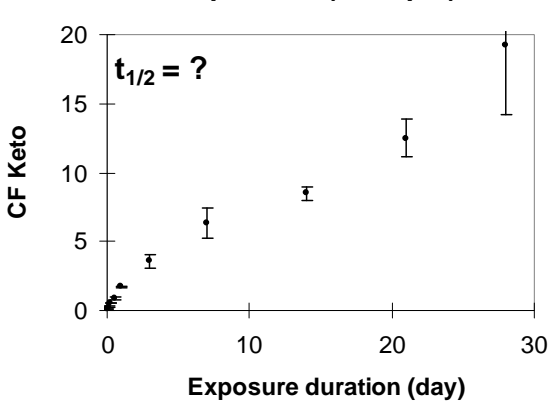

f.

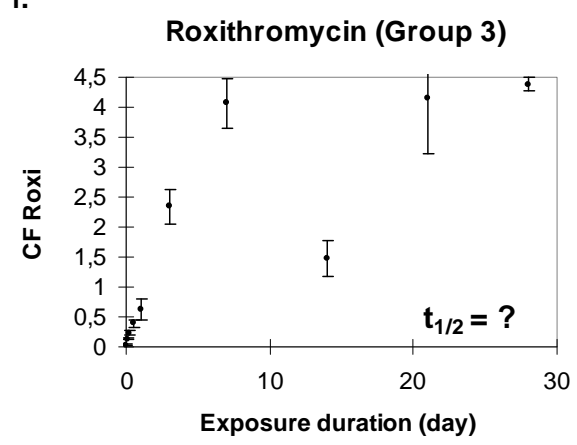

h.

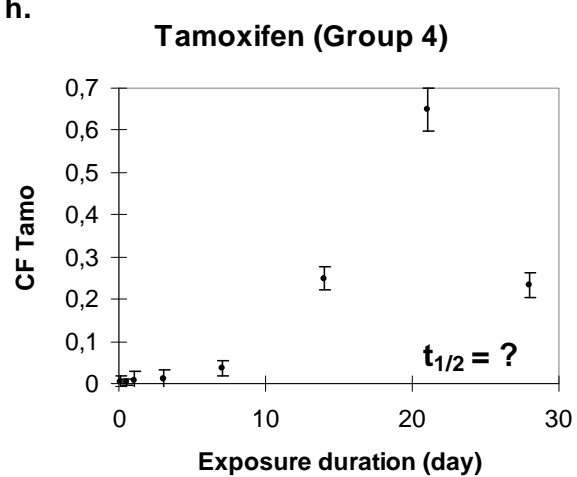

675 Fig. 3. The 4 types of micropollutant accumulation in the POCIS receiving phase, illustrated 676 by a: propranolol (group 1), b: diclofenac (group 1), c: atenolol (group 2), d: ketoprofen 677 (group 2), e: salicylic acid (group 3), f: roxithromycin (group 3), g: paracetamol (group 4), 678 h: tamoxifen (group 4). 
Table 2

681 Characteristics of the 56 micropollutants. Micropollutants are classified according to type of 682 accumulation curve (groups 1-4) and by increasing $\mathrm{t}_{1 / 2}$ followed by increasing $\log \mathrm{K}_{\text {ow }}$.

\begin{tabular}{|c|c|c|c|c|c|c|c|}
\hline Group & Micropollutant & $\mathrm{t}_{1 / 2}$ (day) & $\log \mathrm{K}_{\mathrm{ow}}{ }^{\mathrm{a}}$ & $\begin{array}{c}\log \mathrm{D} \\
(\mathrm{pH}=7.6)\end{array}$ & $\mathrm{pKa}^{\mathrm{a}}$ & $\begin{array}{l}\text { Ionization } \\
(\mathrm{pH}=7.6)\end{array}$ & $\begin{array}{c}\text { Molar } \\
\text { mass }^{\mathrm{a}} \\
(\mathrm{g} / \mathrm{mol})\end{array}$ \\
\hline \multirow{29}{*}{$\begin{array}{c}1 \\
\text { (curvilinear } \\
\text { accumulation) }\end{array}$} & $2,4-\mathrm{DCP}^{*}$ & 5 & 2.88 & 2.49 & 7.44 & - & 163.0 \\
\hline & Prop & 7 & 2.58 & 0.51 & 9.67 & + & 269.3 \\
\hline & Ace & 8 & 1.53 & -0.44 & 9.57 & + & 336.4 \\
\hline & Tim & 9 & 1.34 & -0.82 & 9.76 & + & 316.4 \\
\hline & Oxp & 9 & 2.17 & 0.01 & 9.67 & + & 265.3 \\
\hline & Bet & 10 & 2.54 & 0.47 & 9.67 & + & 307.4 \\
\hline & $\mathrm{t}-\mathrm{BP} *$ & 10 & 3.21 & 3.21 & 10.24 & Neutral & 150.1 \\
\hline & Met & 11 & 1.76 & -0.31 & 9.67 & + & 267.4 \\
\hline & Bis & 11 & 2.20 & 0.13 & 9.67 & + & 325.4 \\
\hline & Lin* & 14 & 2.68 & 2.68 & 11.94 & Neutral & 249.1 \\
\hline & Oxa & 15 & 2.92 & 2.92 & $\begin{array}{c}10.61 \text { and } \\
12.47\end{array}$ & Neutral & 286.7 \\
\hline & Diclof & 19 & 4.26 & 0.66 & 4.0 & - & 296.1 \\
\hline & $\mathrm{T}$ & 20 & 3.37 & 3.37 & 1 & Neutral & 288.4 \\
\hline & Diu & 22 & 2.53 & 2.53 & 13.18 & Neutral & 233.1 \\
\hline & Lora & 23 & 3.53 & 3.53 & $\begin{array}{c}10.61 \text { and } \\
12.46\end{array}$ & Neutral & 321.2 \\
\hline & Atra & 30 & 2.2 & 2.2 & 3.20 & Neutral & 215.7 \\
\hline & t-OP* & 32 & 4.69 & 4.69 & 10.23 & Neutral & 206.3 \\
\hline & Ala & 33 & 3.59 & 3.59 & 1 & Neutral & 269.8 \\
\hline & Acet & 35 & 3.50 & 3.50 & 1 & Neutral & 269.8 \\
\hline & b-E2 & 35 & 3.75 & 3.75 & 10.33 & Neutral & 272.4 \\
\hline & MegA* & 50 & 3.72 & 3.72 & 1 & Neutral & 384.5 \\
\hline & E1* & 50 & 4.31 & 4.31 & 10.33 & Neutral & 270.4 \\
\hline & a-E2 & 53 & 3.75 & 3.75 & 10.33 & Neutral & 272.4 \\
\hline & Carba & 69 & 2.77 & 2.77 & 1 & Neutral & 236.3 \\
\hline & EE2* & 99 & 3.90 & 3.90 & 10.33 & Neutral & 296.4 \\
\hline & Pro* & 347 & 3.62 & 3.62 & 2.75 & Neutral & 376.7 \\
\hline & BPA & 347 & 4.04 & 4.04 & $\begin{array}{c}9.78 \text { and } \\
10.39\end{array}$ & Neutral & 228.3 \\
\hline & 3.4-D* & 693 & 2.35 & 2.35 & 2.78 & Neutral & 162.0 \\
\hline & $\mathrm{P}^{*}$ & 693 & 4.15 & 4.15 & 1 & Neutral & 314.5 \\
\hline
\end{tabular}




\begin{tabular}{|c|c|c|c|c|c|c|c|}
\hline & $4-\mathrm{MBC}^{*}$ & 693 & 5.12 & NA & $\mathrm{NA}$ & Neutral & 254.4 \\
\hline \multirow{13}{*}{$\begin{array}{c}2 \\
\text { (accumulation } \\
\text { with an } \\
\text { inflexion } \\
\text { point) }\end{array}$} & Sot & $?$ & -0.40 & -2.24 & 9.43 & + & 272.4 \\
\hline & Ate & $?$ & 0.43 & -1.64 & 9.67 & + & 266.3 \\
\hline & Sulfa & $?$ & 0.79 & 0.52 & 7.66 & Neutral & 253.3 \\
\hline & $\mathrm{Nad}$ & $?$ & 0.87 & -1.29 & 9.76 & + & 309.4 \\
\hline & Trim & $?$ & 1.28 & 1.15 & 7.16 & Neutral & 290.3 \\
\hline & Furo & $?$ & 1.75 & -1.60 & 4.25 & - & 330.7 \\
\hline & Carb & $?$ & 1.80 & 1.80 & $\begin{array}{c}4.28 \text { and } \\
9.70\end{array}$ & Neutral & 191.2 \\
\hline & 2.4-D acid & $?$ & 2.50 & -2.29 & 2.96 & - & 184.1 \\
\hline & E3 & $?$ & 2.67 & 2.67 & 10.33 & Neutral & 288.4 \\
\hline & Napro & $?$ & 2.99 & -0.42 & 4.19 & - & 230.3 \\
\hline & Keto & $?$ & 3.61 & -0.11 & 3.88 & - & 254.3 \\
\hline & Ibu & $?$ & 3.84 & 1.09 & 4.85 & - & 206.3 \\
\hline & Beza & $?$ & 3.99 & 0.22 & 3.83 & - & 361.8 \\
\hline \multirow{8}{*}{$\begin{array}{c}3 \\
\text { (random } \\
\text { accumulation) }\end{array}$} & Oflo & $?$ & 0.65 & -1.50 & $\begin{array}{c}5.45 \text { and } \\
6.20\end{array}$ & - & 361.4 \\
\hline & Res & $?$ & 1.37 & 1.37 & $\begin{array}{c}9.26 \text { and } \\
10.73\end{array}$ & Neutral & 110.1 \\
\hline & SalA & $?$ & 1.98 & -2.83 & $\begin{array}{c}2.79 \text { and } \\
13.23\end{array}$ & - & 138.1 \\
\hline & Ipr* & $?$ & 2.29 & 2.29 & $\begin{array}{c}12.69 \text { and } \\
13.63\end{array}$ & Neutral & 330.2 \\
\hline & Thi & $?$ & 2.73 & 2.73 & l & Neutral & 240.4 \\
\hline & Roxi & $?$ & 3.00 & 1.51 & $\begin{array}{c}2.29 \text { and } \\
9.08\end{array}$ & + & 837.0 \\
\hline & Feno* & $?$ & 5.28 & 5.28 & l & Neutral & 360.8 \\
\hline & $\mathrm{t}-\mathrm{NP}$ & $?$ & 5.44 & 5.44 & l & Neutral & 220.4 \\
\hline \multirow{5}{*}{$\begin{array}{c}4 \\
\text { (low or no } \\
\text { accumulation) }\end{array}$} & Metro & $?$ & -0.46 & -0.46 & 3,09 & Neutral & 171.2 \\
\hline & Para & $?$ & 0.91 & 0.91 & 9.46 & Neutral & 151.2 \\
\hline & 4-n-OP & $?$ & 5.30 & 5.30 & 10.31 & Neutral & 206.3 \\
\hline & 4-n-NP & $?$ & 5.74 & 5.74 & 10.31 & Neutral & 220.4 \\
\hline & Tamo & $?$ & 6.35 & 5.16 & 8.76 & + & 371.5 \\
\hline
\end{tabular}




\section{$685 \quad$ Table 3}

686 Comparison of kinetic accumulation curves for "pharmaceutical" POCIS.

687 Molecules are grouped by family and by increasing $\log \mathrm{K}_{\mathrm{ow}}$.

\begin{tabular}{|c|c|c|c|}
\hline $\begin{array}{l}\text { Molecule } \\
\text { (group) }\end{array}$ & Family & Type of accumulation & Reference \\
\hline \multirow{2}{*}{$\begin{array}{l}\text { t-Butylphenol } \\
\text { (1) }\end{array}$} & & Linear over 10 days $\left(t_{1 / 2}=10 \mathrm{~d}\right)$ & This study ${ }^{\mathrm{a}}$ \\
\hline & & Linear over 28 days $\left(r^{2}=0.88\right)$ & {$[13]^{\mathrm{b}}$} \\
\hline \multirow{3}{*}{$\begin{array}{c}\text { Bisphenol A } \\
\text { (1) }\end{array}$} & & Linear over 28 days $\left(t_{1 / 2}=693 \mathrm{~d}\right)$ & This study ${ }^{\mathrm{a}}$ \\
\hline & & Linear over 28 days & {$[8]^{\mathrm{c}}$} \\
\hline & & Linear over 10 days $\left(r^{2}>0.97\right)$ & {$[18]^{\mathrm{d}}$} \\
\hline \multirow{3}{*}{$\begin{array}{l}\text { n-Octylphenol } \\
\text { (4) }\end{array}$} & & No accumulation over 28 days & This study $^{\mathrm{a}}$ \\
\hline & $\begin{array}{l}\text { Alkylphenols } \\
\text { and phenols }\end{array}$ & Linear over 28 days & {$[8]^{\mathrm{c}}$} \\
\hline & & No accumulation over 28 days & {$[13]^{\mathrm{b}}$} \\
\hline \multirow{2}{*}{$\begin{array}{l}\text { n-Nonylphenol } \\
\text { (4) }\end{array}$} & & No accumulation over 28 days & This study $^{\mathrm{a}}$ \\
\hline & & No accumulation over 28 days & {$[13]^{\mathrm{b}}$} \\
\hline \multirow{3}{*}{$\begin{array}{l}\text { t-Octylphenol } \\
\text { (1) }\end{array}$} & & Linear over 28 days $\left(t_{1 / 2}=32 \mathrm{~d}\right)$ & This study ${ }^{a}$ \\
\hline & & Linear over 28 days & {$[8]^{\mathrm{c}}$} \\
\hline & & Linear over 28 days $\left(r^{2}=0.63\right)$ & {$[13]^{\mathrm{b}}$} \\
\hline \multirow{2}{*}{$\begin{array}{l}\text { Metronidazole } \\
\text { (4) }\end{array}$} & \multirow{13}{*}{ Antibiotics } & Low & This study ${ }^{\mathrm{a}}$ \\
\hline & & Logarithmic $\left(r^{2}=0.70\right)$ & {$[16]^{\mathrm{g}}$} \\
\hline \multirow{5}{*}{$\begin{array}{l}\text { Sulfamethoxazole } \\
\text { (2) }\end{array}$} & & With an inflexion point & This study $^{\mathrm{a}}$ \\
\hline & & Linear over 25 days & {$[7]^{\mathrm{h}}$} \\
\hline & & Logarithmic $\left(r^{2}=1.00\right)$ & {$[16]^{\mathrm{g}}$} \\
\hline & & Linear over 8 days & {$[14]^{\mathrm{i}}$} \\
\hline & & Linear over 28 days $\left(r^{2}=0.82\right)$ & {$[11]^{j}$} \\
\hline \multirow{4}{*}{$\begin{array}{l}\text { Trimethoprim } \\
\text { (2) }\end{array}$} & & With an inflexion point & This study ${ }^{\mathrm{a}}$ \\
\hline & & Not linear & {$[7]^{\mathrm{h}}$} \\
\hline & & Logarithmic $\left(r^{2}=1.00\right)$ & {$[16]^{\mathrm{g}}$} \\
\hline & & Linear over 8 days & {$[14]^{\mathrm{i}}$} \\
\hline \multirow{2}{*}{$\begin{array}{l}\text { Roxithromycin } \\
\text { (3) }\end{array}$} & & Random & This study $^{\mathrm{a}}$ \\
\hline & & Linear over 25 days & {$[7]^{\mathrm{h}}$} \\
\hline \multirow{3}{*}{$\begin{array}{l}\text { Naproxen } \\
\text { (2) }\end{array}$} & \multirow{5}{*}{$\begin{array}{l}\text { Anti- } \\
\text { inflammatories }\end{array}$} & With an inflexion point & This study ${ }^{a}$ \\
\hline & & Linear over 25 days & {$[7]^{\mathrm{h}}$} \\
\hline & & Linear over 8 days & {$[14]^{\mathrm{i}}$} \\
\hline \multirow{2}{*}{$\begin{array}{l}\text { Ketoprofen } \\
\text { (2) }\end{array}$} & & With an inflexion point & This study ${ }^{\mathrm{a}}$ \\
\hline & & Linear over 25 days & {$[7]^{\mathrm{h}}$} \\
\hline
\end{tabular}




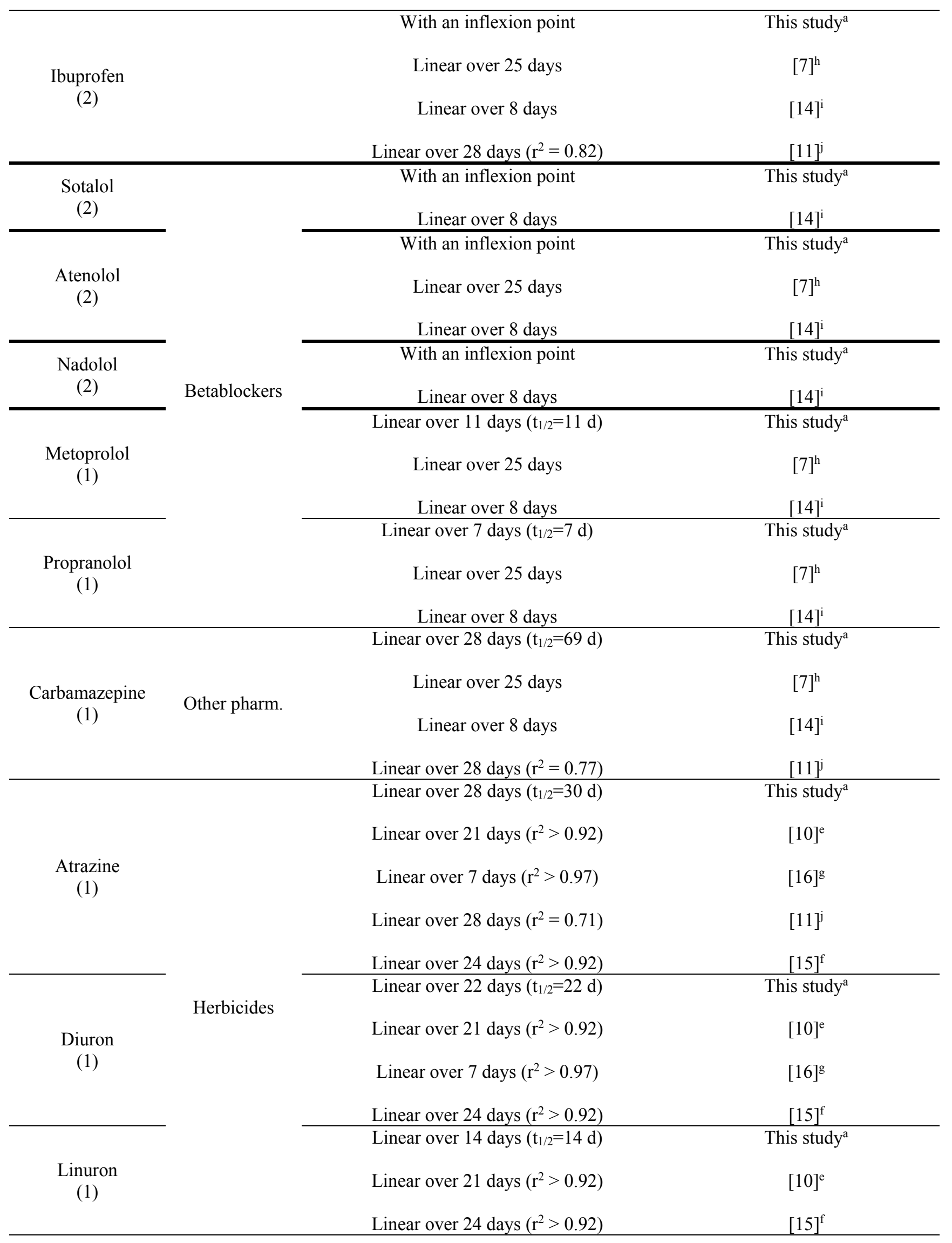




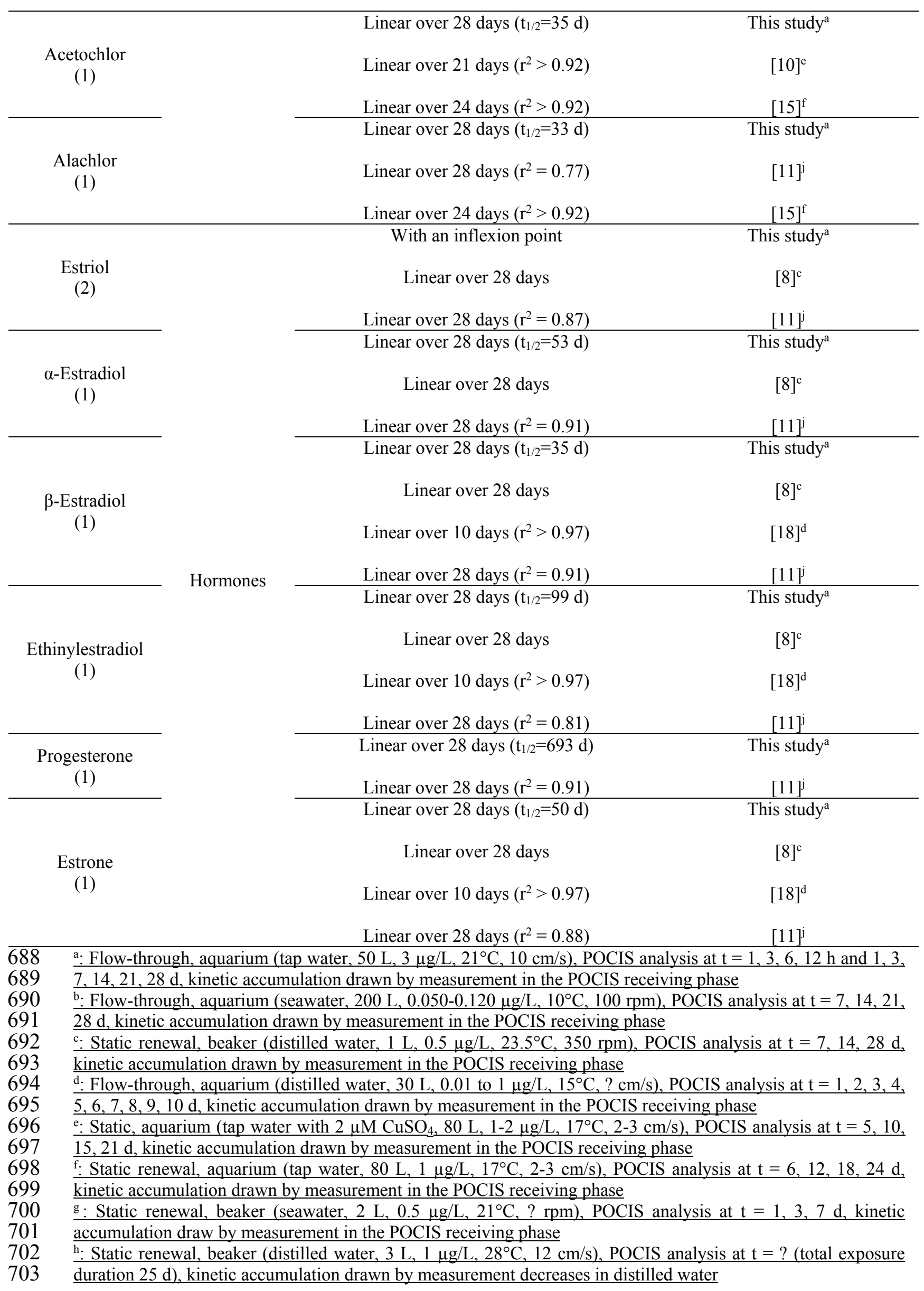


704

705

706

707

708 i. Static, bottle (distilled water, $3 \mathrm{~L}, 2-10 \mu \mathrm{g} / \mathrm{L}, 25^{\circ} \mathrm{C}, 800-900 \mathrm{rpm}$ ), POCIS analysis at $\mathrm{t}=$ ? (total exposure duration $8 \mathrm{~d}$ ), kinetic accumulation drawn by measurement decreases in distilled water j: Static, beaker (distilled water, $2 \mathrm{~L}, 5 \mu \mathrm{g} / \mathrm{L}, 25^{\circ} \mathrm{C}, 450 \mathrm{~cm} / \mathrm{s}$ ), POCIS analysis at $\mathrm{t}=28 \mathrm{~d}$, kinetic accumulation drawn by measurement decreases in distilled water 
Table 4

710 Sampling rates $\left(\mathrm{R}_{\mathrm{s}}\right)$ calculated for the 56 studied micropollutants and comparison against

711 literature data (micropollutants grouped by families and by increasing log $\mathrm{K}_{\mathrm{ow}}$ ). Comparison

712 performed only when studies used the same POCIS configuration and the same calibration

713 conditions as here. Micropollutants in bold characters correspond to unpublished literature Rs.

\begin{tabular}{|c|c|c|c|c|c|c|}
\hline $\begin{array}{l}\text { Molecule } \\
\text { (group) }\end{array}$ & Family & $\log K_{\text {ow }}$ & $\operatorname{Rs}(\mathrm{L} / \mathrm{d})$ & $\begin{array}{c}\text { Rs from } \\
\text { literature }(\mathrm{L} / \mathrm{d})\end{array}$ & Difference (\%) & Reference \\
\hline $\begin{array}{l}\text { Res } \\
\text { (3) }\end{array}$ & \multirow{11}{*}{$\begin{array}{l}\text { Alkylphenols and } \\
\text { phenols }\end{array}$} & 1.37 & a & $\mathrm{b}$ & & \\
\hline $\begin{array}{c}\text { 2.4-DCP } \\
(1)\end{array}$ & & 2.88 & $0.068( \pm 0.005)$ & $\mathrm{b}$ & & \\
\hline $\mathrm{t}-\mathrm{BP}$ & & \multirow[t]{2}{*}{3.21} & \multirow[t]{2}{*}{$0.398( \pm 0.044)$} & 0.120 & -70 & {$[27]$} \\
\hline$(1)$ & & & & 0.170 & -57 & [13] \\
\hline BPA & & \multirow{2}{*}{4.04} & \multirow{2}{*}{$0.245( \pm 0.006)$} & $0.117( \pm 0.019)$ & -52 & {$[8]$} \\
\hline$(1)$ & & & & $0.835( \pm 0.058)$ & 240 & [14] \\
\hline $\begin{array}{l}\text { t-OP } \\
(1)\end{array}$ & & 4.69 & $0.065( \pm 0.005)$ & $0.1204( \pm 0.0110)$ & 85 & {$[8]$} \\
\hline $\begin{array}{c}\mathrm{t}-\mathrm{NP} \\
(3)\end{array}$ & & 5.44 & a & $\mathrm{b}$ & & \\
\hline $\begin{array}{l}\mathrm{n}-\mathrm{OP} \\
\text { (4) }\end{array}$ & & 5.35 & a & $0.010( \pm 0.008)$ & & {$[8]$} \\
\hline $\mathrm{n}-\mathrm{NP}$ & & 5.74 & a & $0.117( \pm 0.012)$ & & {$[8]$} \\
\hline (4) & & 5.14 & & $2.459( \pm 0.131)$ & & {$[14]$} \\
\hline $\begin{array}{l}\text { Metro } \\
\text { (4) }\end{array}$ & \multirow{7}{*}{ Antibiotics } & -0.46 & a & $\mathrm{b}$ & & \\
\hline $\begin{array}{l}\text { Oflo } \\
\text { (3) }\end{array}$ & & 0.65 & a & $\mathrm{b}$ & & \\
\hline Sulfa & & \multirow{2}{*}{0.79} & \multirow{2}{*}{$0.030( \pm 0.003)$} & $0.339( \pm 0.057)$ & 1015 & [14] \\
\hline$(2)$ & & & & $0.118( \pm 0.012)$ & 288 & [11] \\
\hline Trim & & \multirow{2}{*}{1.28} & \multirow[t]{2}{*}{$0.162( \pm 0.014)$} & $0.436( \pm 0.006)$ & 169 & [14] \\
\hline$(2)$ & & & & $0.360( \pm 0.210)$ & 122 & [7] \\
\hline $\begin{array}{l}\text { Roxi } \\
\text { (3) }\end{array}$ & & 3.00 & $\mathrm{a}$ & $0.723( \pm 0.430)$ & & [7] \\
\hline $\begin{array}{l}\text { SalA } \\
(3)\end{array}$ & \multirow{8}{*}{$\begin{array}{l}\text { Anti- } \\
\text { inflammatories }\end{array}$} & 1.98 & $\mathrm{a}$ & $\mathrm{b}$ & & \\
\hline Napro & & \multirow{2}{*}{2.99} & \multirow{2}{*}{$0.084( \pm 0.011)$} & $0.392( \pm 0.024)$ & 368 & [14] \\
\hline (2) & & & & $0.116( \pm 0.053)$ & 38 & [7] \\
\hline $\begin{array}{l}\text { Keto } \\
(2)\end{array}$ & & 3.61 & $0.118( \pm 0.007)$ & $0.135( \pm 0.035)$ & 11 & [7] \\
\hline Ibu & & \multirow{2}{*}{3.84} & \multirow{2}{*}{$0.118( \pm 0.006)$} & $0.348( \pm 0.052)$ & 181 & {$[14]$} \\
\hline$(2)$ & & & & $0.400( \pm 0.008)$ & 223 & {$[11]$} \\
\hline Diclof & & \multirow{2}{*}{4.26} & \multirow{2}{*}{$0.225( \pm 0.009)$} & $0.166( \pm 0.052)$ & -26 & {$[7]$} \\
\hline (1) & & & & 0.170 & -24 & [26] \\
\hline $\begin{array}{l}\text { Oxa } \\
\text { (1) }\end{array}$ & \multirow{2}{*}{ Benzodiazepines } & 2.92 & $0.226( \pm 0.009)$ & $\mathrm{b}$ & & \\
\hline $\begin{array}{c}\text { Lora } \\
\text { (1) }\end{array}$ & & 3.53 & $0.205( \pm 0.006)$ & $\mathrm{b}$ & & \\
\hline $\begin{array}{l}\text { Sot } \\
\text { (2) }\end{array}$ & \multirow{8}{*}{ Betablockers } & -0.40 & $0.036( \pm 0.008)$ & $0.151( \pm 0.021)$ & 386 & {$[14]$} \\
\hline Ate & & \multirow{2}{*}{0.43} & \multirow{2}{*}{$0.025( \pm 0.005)$} & $0.094( \pm 0.015)$ & 331 & {$[14]$} \\
\hline$(2)$ & & & & $0.040( \pm 0.070)$ & 84 & {$[7]$} \\
\hline $\begin{array}{l}\mathrm{Nad} \\
(2)\end{array}$ & & 0.87 & $0.114( \pm 0.009)$ & $0.447( \pm 0.036)$ & 299 & {$[14]$} \\
\hline $\begin{array}{c}\text { Tim } \\
\text { (1) }\end{array}$ & & 1.34 & $0.210( \pm 0.012)$ & $\mathrm{b}$ & & \\
\hline $\begin{array}{l}\text { Ace } \\
\text { (1) }\end{array}$ & & 1.53 & $0.166( \pm 0.008)$ & $\mathrm{b}$ & & \\
\hline \multirow{2}{*}{$\begin{array}{l}\text { Met } \\
\text { (1) }\end{array}$} & & \multirow[t]{2}{*}{1.76} & \multirow{2}{*}{$0.195( \pm 0.012)$} & $0.465( \pm 0.039)$ & 138 & [14] \\
\hline & & & & $0.599( \pm 0.270)$ & 206 & {$[7]$} \\
\hline
\end{tabular}




\begin{tabular}{|c|c|c|c|c|c|c|}
\hline $\begin{array}{c}\text { Oxp } \\
\text { (1) } \\
\end{array}$ & & 2.17 & $0.185( \pm 0.010)$ & $\mathrm{b}$ & & \\
\hline $\begin{array}{l}\text { Bis } \\
(1)\end{array}$ & & 2.20 & $0.161( \pm 0.008)$ & $\mathrm{b}$ & & \\
\hline $\begin{array}{l}\text { Bet } \\
\text { (1) }\end{array}$ & & 2.54 & $0.217( \pm 0.010)$ & $\mathrm{b}$ & & \\
\hline \multirow{2}{*}{$\begin{array}{c}\text { Prop } \\
(1)\end{array}$} & & \multirow{2}{*}{2.58} & \multirow{2}{*}{$0.165( \pm 0.009)$} & $0.917( \pm 0.084)$ & 455 & [14] \\
\hline & & & & $0.980( \pm 0.345)$ & 493 & [7] \\
\hline $\begin{array}{c}\text { Beza } \\
\text { (2) }\end{array}$ & \multirow{2}{*}{ Lipopenics } & 3.99 & $0.146( \pm 0.034)$ & $\mathrm{b}$ & & \\
\hline $\begin{array}{c}\text { Feno } \\
\text { (3) }\end{array}$ & & 5.28 & a & $\mathrm{b}$ & & \\
\hline $\begin{array}{c}\text { Para } \\
(4)\end{array}$ & \multirow{6}{*}{$\begin{array}{c}\text { Other } \\
\text { pharmaceuticals }\end{array}$} & 0.91 & $\bar{a}$ & 0.020 & 80 & [26] \\
\hline $\begin{array}{c}\text { Furo } \\
\text { (2) }\end{array}$ & & 1.75 & $0.129( \pm 0.007)$ & $\mathrm{b}$ & & \\
\hline \multirow{4}{*}{$\begin{array}{l}\text { Carba } \\
(1)\end{array}$} & & \multirow{4}{*}{2.77} & \multirow{4}{*}{$0.188( \pm 0.005)$} & $0.348( \pm 0.116)$ & 86 & {$[7]$} \\
\hline & & & & 0.400 & 113 & [26] \\
\hline & & & & $0.561( \pm 0.024)$ & 199 & [14] \\
\hline & & & & $0.288( \pm 0.009)$ & 54 & [11] \\
\hline $\begin{array}{c}\text { Carb } \\
\text { (2) }\end{array}$ & \multirow{4}{*}{ Fongicides } & 1.80 & $0.213( \pm 0.004)$ & $\mathrm{b}$ & & \\
\hline $\begin{array}{l}\text { Ipr } \\
(3) \\
\end{array}$ & & 2.29 & a & $\mathrm{b}$ & & \\
\hline $\begin{array}{l}\text { Thi } \\
\text { (3) }\end{array}$ & & 2.73 & a & $\mathrm{b}$ & & \\
\hline $\begin{array}{l}\text { Pro } \\
(1)\end{array}$ & & 3.62 & $0.208( \pm 0.004)$ & 0.098 & -53 & {$[5]$} \\
\hline $\begin{array}{c}2.4-\mathrm{D} \\
(2)\end{array}$ & \multirow{15}{*}{ Herbicides } & 2.50 & $0.044( \pm 0.009)$ & 0.092 & 111 & {$[5]$} \\
\hline \multirow{5}{*}{$\begin{array}{c}\text { Atra } \\
\text { (1) }\end{array}$} & & \multirow{5}{*}{2.20} & \multirow{5}{*}{$0.189( \pm 0.006)$} & 0.240 & 27 & {$[5]$} \\
\hline & & & & 0.042 & -78 & {$[9]$} \\
\hline & & & & $0.228( \pm 0.041)$ & 21 & [15] \\
\hline & & & & 0.214 & 13 & [16] \\
\hline & & & & $0.239( \pm 0.008)$ & 26 & [10] \\
\hline $\begin{array}{c}3.4-\mathrm{D} \\
(1)\end{array}$ & & 2.35 & $0.241( \pm 0.038)$ & $\mathrm{b}$ & & \\
\hline Diu & & & & $0.199( \pm 0.038)$ & 1 & [15] \\
\hline $\begin{array}{c}\text { Diu } \\
(1)\end{array}$ & & 2.53 & $0.198( \pm 0.005)$ & 0.086 & -56 & [16] \\
\hline & & & & 0.247 & 25 & [10] \\
\hline Lin & & 2.68 & $0.182( \pm 0.008)$ & $0.204( \pm 0.037)$ & 12 & [15] \\
\hline (1) & & 2.00 & $0.102(-0.000)$ & 0.236 & 30 & [10] \\
\hline Acet & & 3.50 & $0.195( \pm 0.006)$ & $0.241( \pm 0.034)$ & 23 & [15] \\
\hline$(1)$ & & 5.00 & $0.170(+0.000)$ & 0.225 & 15 & {$[10]$} \\
\hline $\begin{array}{c}\text { Ala } \\
\text { (1) }\end{array}$ & & 3.59 & $0.192( \pm 0.006)$ & $0.205( \pm 0.004)$ & 7 & [15] \\
\hline $\begin{array}{l}\text { E3 } \\
\text { (2) }\end{array}$ & & 2.67 & $0.185( \pm 0.009)$ & $0.157( \pm 0.004)$ & -4 & {$[8]$} \\
\hline $\begin{array}{c}T \\
(1) \\
\end{array}$ & & 3.37 & $0.280( \pm 0.007)$ & $\mathrm{b}$ & & \\
\hline $\begin{array}{c}\text { MegA } \\
\text { (1) }\end{array}$ & & 3.72 & $0.265( \pm 0.005)$ & $\mathrm{b}$ & & \\
\hline $\begin{array}{c}\text { a-E2 } \\
(1)\end{array}$ & & 3.75 & $0.239( \pm 0.014)$ & $0.122( \pm 0.003)$ & -49 & {$[8]$} \\
\hline & Hormones & & & $0.115( \pm 0.014)$ & -48 & {$[8]$} \\
\hline b-E2 & Hormones & 3.75 & $0.221( \pm 0.013)$ & $0.693( \pm 0.092)$ & 214 & [14] \\
\hline & & & & 0.129 & -42 & [28] \\
\hline & & & & $0.222( \pm 0.053)$ & -15 & {$[8]$} \\
\hline EE2 & & 3.9 & $0.260( \pm 0.013)$ & 0.180 & -31 & [9] \\
\hline & & & & $0.853( \pm 0.143)$ & 227 & [14] \\
\hline $\begin{array}{c}P \\
(1)\end{array}$ & & 4.15 & $0.346( \pm 0.008)$ & $\mathrm{b}$ & & \\
\hline E1 & & 4.31 & $0.230( \pm 0.012)$ & $0.120( \pm 0.018)$ & -48 & {$[8]$} \\
\hline (1) & & (.J1 & $0.250(1+0.012)$ & 0.150 & -35 & [9] \\
\hline
\end{tabular}




\begin{tabular}{|c|c|c|c|c|c|c|}
\hline & & & & $0.699( \pm 0.087)$ & 204 & {$[14]$} \\
\hline $\begin{array}{c}\text { Tamo } \\
(4)\end{array}$ & & 6.35 & a & $\mathrm{b}$ & & \\
\hline $\begin{array}{c}\text { 4-MBC } \\
\text { (1) }\end{array}$ & UV filter & 5.12 & $0.215( \pm 0.004)$ & $\mathrm{b}$ & & \\
\hline
\end{tabular}

a: not calculated because randomly or poorly accumulated in the POCIS (i.e. qualifying

715 as group-3 or group-4 molecules).

716 b: never determined with this POCIS configuration and in these conditions. 

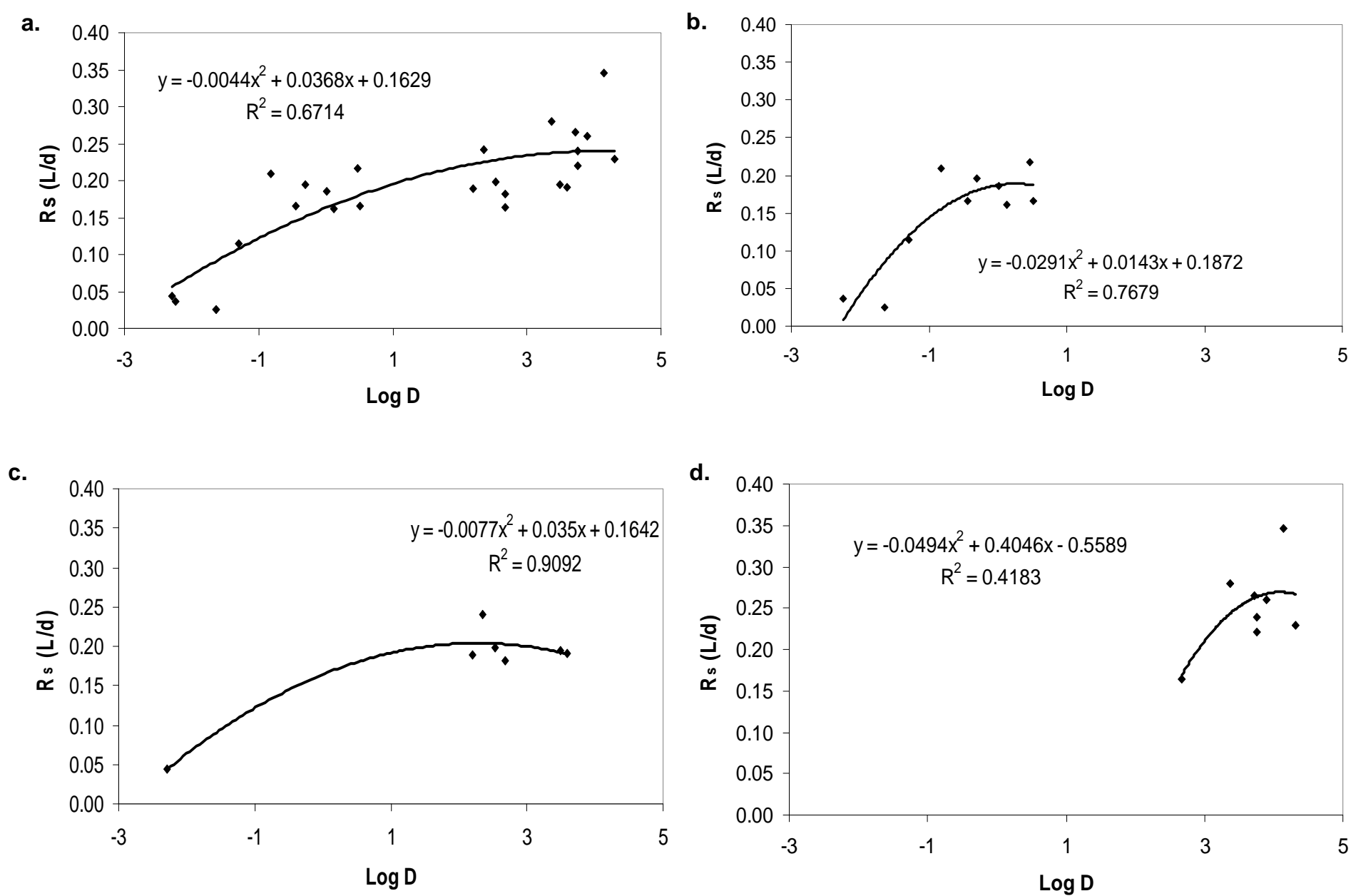

719 Fig. 4. Sampling rate $\left(\mathrm{R}_{\mathrm{s}}\right)$ versus $\log \mathrm{D}$ for a) betablockers, herbicides and hormones, b) betablockers only, c) herbicides only, d) hormones only. 